\title{
Mekânın, Zamanın ve Eğlencenin Sınırlarında Osmanlı'da Gazinolar
}

\author{
Oya ŞENYURT ${ }^{1}$
}

\section{Öz}

Gazinolar, Osmanlı toplumunun eğlence mekânlarının arasına Tanzimat'tan sonra girmiştir. 19. yüzyılın ikinci yarısında yeni gazinolar inşa edilmekle birlikte, çoğu kahvehane olan başka mekânların dönüştürülmesiyle gazinolar kullanılır hale getirilmiştir. Meddah'tan pandomime, Karagöz'den tiyatro oyunlarına kadar gerek geleneksel gerekse batılı eğlence biçimlerinin sunulduğu gazinolar, yönetimin sıkı kontrolü altındadır. Oyuncular, izleyiciler ve eğlence programlarının denetimden geçtiği bir ortamda içki satışıyla birlikte güvenlik tedbirlerinin alınması için çeşitli kurallar gündeme getirilmiştir. Makalede Osmanlı'da gazino açma girişimleri, gazinoların işletilmesindeki güçlükler, gazinonun mekânları ve eğlenceleri çeşitli başlıklar altında genel olarak ele alınmıştır. Marjinal bir mekân olarak görülen gazinoların belirli semtlerde açılmalarına izin verilmiş ve yönetim tarafından içki ve eğlencenin zamanı ve mekânı sınırlanarak gazinoların kamu güvenliği için daha az zararlı hale gelmesi amaçlanmıştır.

Anahtar Kelimeler: Gazino, Osmanlı, 19. Yüzyıl, Eğlence.

\section{Casinos in the Ottoman Empire at the Boundaries of Space, Time and Entertainment}

\begin{abstract}
Casinos became one of the entertainment venues of the Ottoman society after the Tanzimat. Although new casinos were built in the second half of the 19th century, other venues, most of which were coffee houses, were converted into use. From meddah to pantomime, from Karagöz to theater plays, the casinos, where both traditional and western forms of entertainment are offered, are under the strict control of the administration. In an environment where actors, viewers and entertainment programs are inspected, various rules have been brought to the agenda for taking security measures with the sale of drinks. In the article, the attempts to open a casino in the Ottoman Empire, the difficulties in the operation of the casinos, the venues and entertainments of the casino are discussed in general under various headings. Casinos, which are seen as marginal places, were allowed to open in certain districts and the management aimed to make the casinos less harmful to public safety by limiting the time and place of drinking and entertainment.
\end{abstract}

Key words: Casino, Ottomans, 19th Century, Entertainment.

\footnotetext{
${ }^{1}$ Kocaeli Üniversitesi, Mimarlık ve Tasarım Fakültesi, Mimarlık Bölümü, Kocaeli Türkiye İlgili Yazar/Corresponding author: oya.senyurt@kocaeli.edu.tr. 


\section{Giriş}

19. yüzyııın ikinci yarısından itibaren adım adım kabuk değiştiren Osmanlı toplumundaki değişim, eğlence hayatında da kendini önce İstanbul'da hissettirmiştir. Hamam, meyhane, kahvehane, mesirelik gibi geleneksel eğlence dünyasında vakit geçiren Osmanlı toplumu, 19. yüzyılın ikinci yarısından sonra farklı özellikler gösteren eğlence mekânlarını deneyimlemiştir. Bu dönemde Pera'da modern kafeler, Galata balozları yanında içkili, müzikli gazinolar, müzikli revülü kafeler (café chantant) rağbet bulmaya başlamıştır².

Bu makaleye konu olan gazinolar müzikli program eşliğinde içki içilip yemek yenilen, çoğunda dans da edilen kapalı ya da açık alanlarda işletilen eğlence yerleridir. Gazino sözcüğü Türkçe'ye İtalyanca "kır evi” anlamına gelen "casino" sözcüğünden bozularak gelmiştir (Zat, 2019, s. 180). "Gazino”nun Türkçe Sözlük’te birinci anlamı yemek yenilen, gösteri izlenen, bazen oyun sergilenen eğlence yeri olarak tanımlanmıştır. İkinci anlamı ise büyük kahvehane ve birahanedir (1992, s. 527). Türkçe Sözlük'teki ikinci anlam dikkate alındığında gazinoların Geç Osmanlı dünyasına kahvehanelerin ve meyhanelerin dönüştürülmesiyle girdiğini söylemek yanlış olmayacaktır. Geleneksel eğlence anlayışının en önemli öğesi olan kahvehaneler (Resim 1) bu dönemde gerek müdavimleri gerekse hizmetleri ve mekânları bağlamında değişime uğramıştır.

20. yüzyılın başında yapılan tespitler İstanbul'da mahalle aralarında veya cami yanında yer alan geleneksel kahvehaneler dışında Batı ülkelerindeki otellerin yemek salonlarıyla aynı kategoride tutulacak otel ve han kahvehanelerinin ortaya çıktığını göstermektedir. Müdavimlerine göre kahvehaneler nitelik kazanmış, küçük tüccar ve mütevazı sınıfların devam ettiği mekânlar haline gelmiştir (Deaver, 1995, s. 225-226). Modernleşme ile geleneksel eğlence anlayışındaki yapının değişimi bazı kahvehanelerin gazinolara dönüşerek yeni eğlence mekânlarına dâhil olmasını gerektirmiştir. Tanzimat'tan sonra kimi örnekler kahvehane-gazino ya da meyhane-gazino arasındaki ayrım kesinleşmeden ikili bir yapı içinde faaliyet göstermiştir (Gürbüz, 2020, s. 11). Çalgılı kahveler ile çalgılı ve şarkılı gazinolar arasında fonksiyon bakımından önemli bir fark yoktur. Bu mekânların çoğu, gündüz kahve, gece de meyhane ve çalgılı gazino olarak kullanımaktadır. Aynı zamanda bir kısmı birahane olarak kullanılır ve böyle anılırdı (Aliji, 2019, s. 21). N. Meriç'e göre modernleşmeyle birlikte kahvehanelere müziğin girmesi kahvehanelerin "gazino" olarak adlandırılmasına neden olmuştur (Meriç, 2010, s. 143, 384-385).

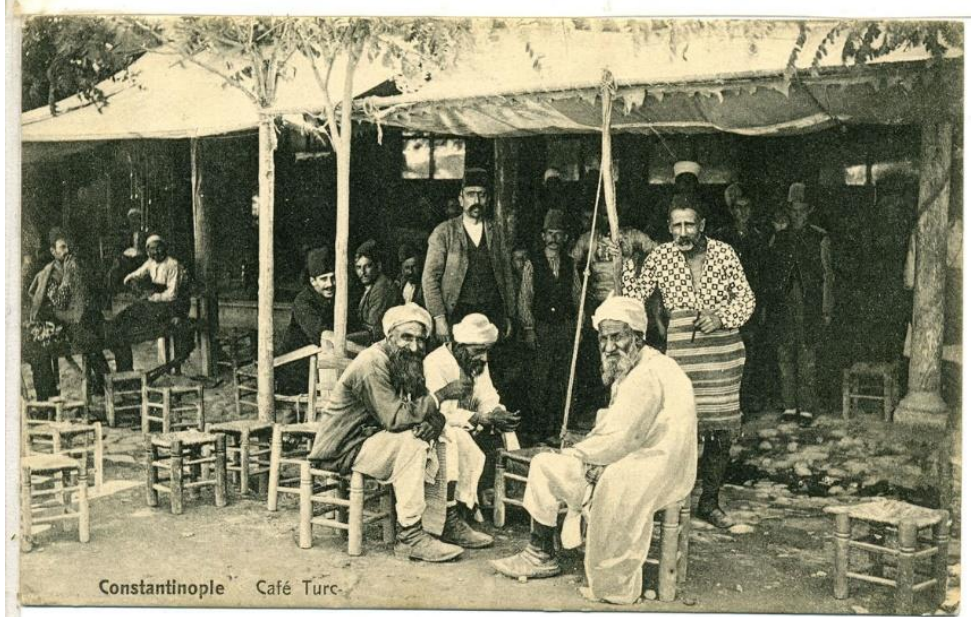

Resim 1. İstanbul'da geleneksel kahvehane (İ.B.B. Atatürk Kitaplığı, Krt_001946)

\footnotetext{
2 “Eğlence Hayatı”, Dünden Bugüne İstanbul Ansiklopedisi, C.: 3, s. 143.
} 
Geleneksel kır kahvehanelerinde başta müzik dinletileri olmak üzere çeşitli programlar düzenlenmiştir. Bu kır kahvehanelerinde yer alan kulübe benzeri mekânlardan, gelen misafirlere çay, kahve gibi içecekler ve hatta ufak tertip yiyecekler de servis edilmektedir. Bu gelişmeler neticesinde söz konusu kahvehaneler zamanla gazino olarak anılmaya başlamıştır (Yapar, 2014, s. 60). Diğer taraftan müzikli eğlence programlarının çalgılı meyhaneleri andırmasından dolayı gazinolara "meyhanelerin alafrangası" da denilmiştir (Zat, 2005, s. 105). Alaturka sazların arasına piyano, keman eklenmesi ve eski meyhanelerdeki sofra ve hasır iskemle yerine masa ve sandalye kullanılması alafrangalığın bir göstergesi (Kabagöz, 2016, s. 74-75) olarak düşünülmüş olmalıdır.

Gazinoların faaliyetlerinin ve hizmetlerinin benzerlik gösterdiği ya da dönüşebildiği diğer bir sosyal tesis kulüplerdir. Rıfat Müeyyed tarafından 1917 yılında Yeni Mecmua Dergisi'nde yayınlanan bir makalede gazino ve kulüpler birbirleriyle karşılaştırılmıştır. Rıfat Müeyyed'e göre, "spor kulübü unvanı verilen bir mahalde birleşen beş yüz kişiden mesela on kişi binicilik, on kişi denizcilik seksen kişi de avcılık merakını takib ettiği halde yüz kişi gündüz ve gece kumarla meşgul ve üç yüz kişi de kadınlarla kırıştırmaya meclûb olsa burası kulüp nikâbını takınmış bir gazinodur". Yazar bu görüşünü kuvvetlendirmek için Montecarlo'daki "Sporting Kulüp"ü örnek gösterir ve Fransa'da böyle kulüp unvanı verilmiş gazino mahiyetinde pek çok yapı olduğundan söz eder. Rıfat Müeyyed'e göre İstanbul'da açılan kulüpler de gazino mahiyetini almıştır. Diğer taraftan kulüplerin milli olabildiği ve hem sosyal hem de siyasi sebeplerle kurulabildiği de dile getirilmiştir (Müeyyed, 1917, s. 147-148). R. Müeyyed kumar oynatılmasının ve kadınlarla karşılaşmanın gazinoları spor veya avcılık amacıyla kurulan kulüplerden farklılaştırdığını belirtir. Ayrıca gazinolar kulüplerden ayrı olarak siyasi sebeplerle de kurulmamaktadır. Bu durumda Osmanlı'nın son dönemlerinde gazinoların tamamen eğlenceye odaklanılan ve kişilerin hobileri ya da hünerleri çerçevesinde faaliyet gösterme zorunluluğu taşımayan mekânlar olduğu sonucuna varılabilir. Özel müdavimleri olmakla birlikte kulüplerden farklı olarak gazinolar herkese açık mekânlardır.

İstanbul'daki ilk kulüp Asım Paşa Konağı'nda 1870 yılında açılmıştır. Bu kulübe vekiller, ileri gelenler ve yüksek dereceli memurlar üye olarak kabul edilirlerdi ${ }^{3}$. Büyükada'da Yat Kulübü ${ }^{4}$ (Resim 2) ve Beyoğlu'ndaki Cercle d'Orient dönemin etkin faaliyet gösteren diğer kulüpleri arasındadır. Cercle d'Orient'ın üyeleri de şehrin önde gelen kişileri ve diplomatlardan oluşmaktaydı (Duhanî, 1984, s. 93).

\footnotetext{
${ }^{3}$ Kurucuları ilk önce "kulüp" gibi yabancı bir sözcüğün kullanılmasını uygun bulmadıklarından "Encümen-i Ülfet" deyimini kullanmıştır. Bkz. (Sevengil, 2014, s. 249, 251).

${ }^{4}$ Büyükada Yat Kulübü ise 1906 yılında İngiliz uyruklu bir kişi tarafından kurulmuştur.
} 


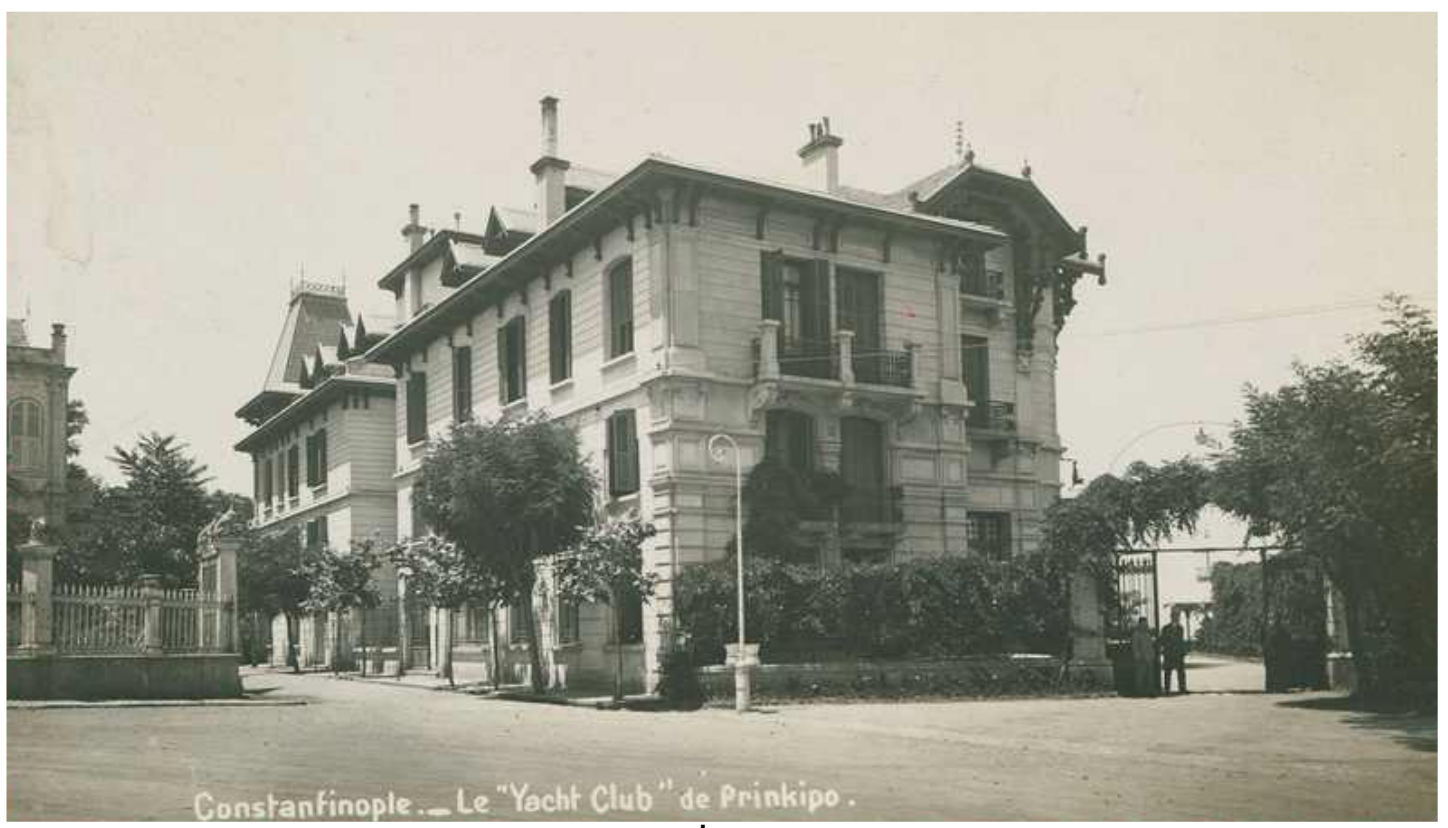

Resim 2. Büyükada Yat Kulübü (İ.B.B. Atatürk Kitaplığı, Krt_026501)

Anlaşılabileceği gibi gazinolar; meyhane, kahvehane, kulüp gibi pek çok yapının işlevleri ile birbirine karışan bir ortamda faaliyetlerini sürdürmüşlerdir. 19. yüzyılda batılı biçimdeki eğlence anlayışının yaygınlaşması halkın gazinolara ilgisini de arttırmıştır. Gazinolar özellikle içinde satılan müskirat sebebiyle oldukça fazla gelir getiren bir mekân olarak çoğu girişimcinin ilgisini çekmiştir. Buna rağmen devletin sıkı kontrolü altında tutulan gazinolarda içki satma hakkının kolaylıkla elde edilemediği bilinmektedir. Gazinoların varlık gösterdiği mekânlar ve açılış-kapanış saatleri ile eğlenceler sıkı bir denetime tabi tutulmaktadır. Bu makalede, batılı eğlence anlayışının ilgi çekiciliği ile bu ilgiyi kontrol etmeye çalışan yönetimin kararları arasında kalan Osmanlı gazinolarının mekânlarının ve eğlencelerinin neler olduğu ve ne tür müdahalelere uğradığı arşiv belgeleri bağlamında değerlendirilmiştir.

\section{Gazino Açma Girişimleri ve Getirilen Sınırlamalar}

İstanbul'da ilk gazinonun, Fransız yazar Jacques Natanson'un Bulgar kökenli ve Yahudi olan babası Natanson tarafından, Tanzimat döneminde açılmış olan Tepebaşı Gazinosu olduğu ifade edilir (Yöre, 2012, s. 893). Tanzimat dönemiyle başlayan gazino açma girişimleri bir emsal oluşturmuş yerli ya da yabancı pek çok müteşebbisin dikkatini çekmiştir. Boğdanlı Gomsi Radiyoviç tarafından sunulan 1851 yılına ait arzuhal tercümesi gazino açmaya karar veren bir kişinin nasıl bir yol izlediğini ve yönetimle karşı karşıya gelmesi durumunda nasıl bir sürecin takip edildiğini anlatması açısından önemlidir. Gomsi Radiyoviç Avrupa'nın tüm büyük şehirlerinde gazino ya da kulüp adı altında halka ait cemiyet mahalleri olduğunu ve her statüde insanın bu mahallerde türlü yiyecek ve içecekleri bulabildiğini tarif etmiştir. Ayrıca Avrupa'daki gazinolara ilişkin uygulamaları örnek vererek gazinolar açma isteğini yönetime sunmuştur. Açılacak gazinoların bir müdürün idaresinde olacağını ve İstanbul'da da açılmasına izin verildiği takdirde devletin menfaatine yarayan pek çok yönünün olduğunu vurgulamış, yönetimden izin koparabilmek için gazinoların çeşitli yararlııklarını dile getirmiştir. Gomsi Radiyoviç biri Beyoğlu'nda ve diğeri Galata'da olmak üzere biri muteber diğeri ise sıradan kişilere tahsis edilmek üzere iki gazino açma niyetindedir. Beyoğlu'nda kış mevsiminde iki kez, ticaret merkezi olan Galata'da ise yaz mevsiminde bir kez balo vermek üzere bu alanı yönetmeyi mahir kişilerin eline bırakarak gazinolar açmaya talip olmuştur. Gomsi Radiyoviç'in ikna çalışmalarının başarılı olduğu söylenebilir. Yönetim 
en az bir seneliğine gazino açmanın saltanatın yararına olacağına kanaat getirmiştir. Ancak gazinoya gidip gelenlerin hareketlerine dikkat edilmesi hakkında da uyarıda bulunmuştur (BOA., HR.TO., Dosya no: 416, Gömlek no: 24).

Gomsi Radyoviç'in Beyoğlu ve Galata'da Efrenç mahallelerinde açmak istediği gazinolara izin verilmesinde mahzur olmadığına ve emsallerinin de olduğuna Zabtiye'nin yaptığı tahkiklerle karar verilmiştir. 1851 yılında Beyoğlu'nda İngilizlere, Galata'da ise Avusturyalılara ait olmak üzere iki gazino Gomsi Radiyoviç'in açmak istediği gazinolara emsal olarak gösterilmiştir. Gomsi Radiyoviç ise gazinoya gelecek kişileri statülerine göre ayırarak birine beyzade, elçi, muteber tüccar diğerine muteber esnaf, bezirgan girecek biçimde düzenlemeyi tasarlamıştır. Bu sebeple iki ayrı binaya ihtiyaç varsa da bulunamaması halinde bir büyük binaya yerleşmeye razıdır. Bu gazinolara hal ve hareketleri meçhul adamların giremeyeceğini taahhüt eden Gomsi Radiyoviç, gazinoların muteber tüccarlardan iane alınarak açılabileceğini hatırlatarak gerekli parayı kendi imkanlarıyla sağlayabileceğini bildirmiştir (BOA., A.DVN., Dosya no: 74, Gömlek no: 81).

Boğdanlı Gomsi Radiyoviç'in Galata ve Beyoğlu'ndaki Frenk Mahallesi'nde iki gazino açmak için yaptığı başvuru sonucunda bu mekânların eğlence alanı ya da lokanta olarak kullanılmakta olduğuna ve mevcut örneklerde bir "fenalık" ortaya çıkmadığına karar verilmiştir. Söz konusu gazinolardan birinin açılması için Gomsi Radiyoviç'e izin verilerek diğerinden vazgeçilmesi, emsali gibi kullanılmasına dikkat edilmesi ve uygun mahalde açılması istenmiştir (BOA., A.MKT.MVL., Dosya no: 52, Gömlek no: 19). Boğdanlı Gomsi Radiyoviç'in gazino açma girişimi yönetim nezdinde birkaç noktanın önemli görüldüğünü ortaya çıkarmaktadır. Bunlardan biri Osmanlı'ya dışardan gelen gazino mekânının başkentte emsallerinin olup olmadığı konusudur. Böyle bir mekânın tecrübe edilmesi yerleşmiş bir kanının ortaya çıkmasını sağlayarak karar verme anında bu bilginin kullanılmasını gerektirir. Diğer bir deyişle doğru kararı vermek için mekânın kullanımının tecrübe edilmesi önemli bir kıstastır. Diğer taraftan Gomsi Radiyoviç'in yapmak istediği gazino için gösterilen iki emsal, Radiyoviç'in kahvehanelerden dönüştürülen bir gazino yapmayacağı ve başkent İstanbul'da örneği az olan bir gazino açacağı sonucunu ortaya çıkarır. Bu gazinolarda statü farkına bağlı olarak bir mekânsal ayrım olmakla birlikte müdavimlerini oluşum anında belirleyen bir durum da söz konusudur. Diğer bir deyişle Gomsi Radiyoviç'in gazinosunun açılması için muteber bir tüccar grubunun maddi destekte bulunma potansiyelinin olduğu ima edilmiştir. Açılacak söz konusu gazinolar Frenk mahallelerinde yer alacak olmaları sebebiyle karnaval ya da yılbaşı baloları için yabancı, gayrimüslim ve Levantenlere hizmet edecektir. Dolayısıyla Müslüman halkın bu mekânlara ilgisinin daha az olacağı tahmin edilebilir. Bunun dışında Gomsi Radiyoviç'in açmak istediği gazino için bir yıllığına izin verilmiştir. Gazinoların açılması hakkındaki karar her yıl yenilebilmektedir. Genellikle bir sene önce açılan bir gazinonun bir fenalık ortaya çıkmamak ve kumar oynatılmamak şartıyla açılmasına tekrar izin verilmektedir (BOA., HR.MKT., Dosya no: 54, Gömlek no:64).

Gomsi Radiyoviç'in girişimi yeni oluşturacağı bir mekânın gazino yapılmasına ilişkindir. Ancak bazı girişimciler sahip oldukları mekânları dönüştürerek gazino haline getirmek için başvuruda bulunmuştur. Özellikle Müslüman ve Hıristiyan'ın bir arada bulunduğu mahallelerde bu tip mekânsal dönüşümler mahalle halkları arasında kuşku ve rahatsızlık yaratmıştır. Söz gelimi, gazinoların bazı mekânların dönüştürülmesiyle oluşturulması ve içinde içki satışının yapılabilme intimali mahalle halkı tarafından olumlu karşılanmamaktaydı. Zabtiye Müşiriyeti'ne bir mahalle halkının verdiği müzekkirede bakkal Nikola'nın Aksaray civarında tasarrufunda olup, gazinoya dönüştürülmek üzere kontrat yaptığı bakkal dükkânından şikâyetçi olunmuştur (BOA., HR.MKT., Dosya no: 322, Gömlek no: 34). Bir başka örnekte ise 20 Recep 1274/6 Mart 1858 tarihinde 
Üsküdar'da Ayazma Mahallesi'nde bulunan gazinoya dönüştürülmüş bir kahve dükkânının tekrar kahvehane yapılması için mahalle halkı tarafından bir müzekkire verilmiştir. Yönetim ise gazinoların kahvehanelerle aynı işlevi gördüğünü belirterek halkı ikna etmeye çalışmıştır. Gazinonun içinde müskirat satılmadığı için mahalle halkını da rahatsız edecek bir durumun ortaya çıkmadığı bildirilerek herhangi bir müdahalenin yapılmasına gerek duyulmamıştır (BOA., A.MKT.NZD., Dosya no: 253, Gömlek no: 21).

Frenk (Hıristiyan) mahalleleri gazino açmak için yönetim tarafından uygun görülen kent mekânları olmakla birlikte mahalle arasında gazino açılması ve müskirat satılması için bazı dükkan ve mağazaların kiralanması sırasında tahkikat yapılmadan kontrat düzenlenmesi uygun görülmemekte ve Zabtiye tarafından bu konuya özen gösterilmesi istenmekteydi (BOA., A.MKT.NZD., Dosya no: 293, Gömlek no: 77). Gayrimüslimlerin kaldığı mahallelerde bazı gazinolar okullara gelir getirmesi için işletilmekteydi. 13 Muharrem 1291/2 Mart 1871 tarihinde Salmatomruk Acı Çeşme Caddesi'nde bulunan 31 numaralı gazinonun şahsa ait olmayıp Rum milleti kilisesinin akaratından olduğu belirtilerek elde edilen gelirin erkek sıbyan mektebine bırakıldığı ve yine Salmatomruk'ta bulunan 86 numaralı gazinonun gelirinin de kız mektebine ait olduğu ifade edilmiştir (BOA., ŞD., Dosya no: 2878, Gömlek no: 32).

Gazinoların müskirat satanları Müslüman ahalinin rahatsızlığına sebep olmakla birlikte müşteri profili de bir başka rahatsızlık sebebi olarak görülmekteydi. Osmanlı tebaası ve diğer devlet tebaasından olan lokanta, otel, han ve gazino sahipleri müşterilerinden sorumlu tutulmaktaydılar. Hükümete verecekleri senet suretinde yapmaları gerekenler 1877 yılında kayıt altına alınmıştır. Bu kişilerin sahip oldukları mekânın numarası, sokağı veya mahallesi belirtilerek toplam ne kadar müşteri gelirse tümünün isimlerinin ve hangi devlet tebaasında bulunduklarının bir deftere yazılması istenmiştir. Gelen müşterilerin nereden geldikleri ne iş yapacakları nereye gideceklerini içeren bir defter tutulmaktadır. Lokanta, otel, han ve gazino sahiplerinden Saltanat-ı seniyye'nin kurallarına uygun davranmaları istenmiş ve sahip oldukları işletmelerde tezkiresiz veya pasaportsuz kimselerin barındırılmamaları ve herhangi bir kişinin şüpheli hallerini gördükleri anda hükümete şikâyet etmeleri talep edilmiştir. Tutulan defterin kontrolü zabıta ve diğer hükümet memurları tarafından yapılmaktadır (BOA., HR.ID., Dosya no: 183, Gömlek no: 9).

\section{Gazino İşletmenin Güçlükleri: Gazinonun Yerleri ve Zamanları}

Yönetim gazinoların varlık gösterdiği alanlara ve gazinoların faaliyette olduğu saatlere sınır getirmesine rağmen, gazino işletmecilerinin kimi zaman bu sınırları aşma eğilimi kimi zaman da halkın müskirat satışı ve müşteri profilinden rahatsızlık duymaları mahalle halkı ve gazino işletmecileri arasında çekişmelerin yaşanmasına neden olmaktaydı. Söz gelimi, Beyoğlu'nda Emin Cami civarında müskirat satılan gazinoda müskirat satışının men edilmesi için mahalle halkı bir arzuhal sunmuştur. Şura-yı Devlet'e havale edilen arzuhallerinde mahalle halkı Beyoğlu'nda, Emin Cami-i Şerifi civarındaki İlardi Sokağı'nda ruhsatlı, on numaralı gazinonun serserilerin mekânı haline geldiğini, gece gündüz çeşitli tartışma, çekişme ve rezilliklerin yaşandığını ifade etmiştir. Önlem alınmazsa ilerleyen zamanlarda daha büyük sorunlarla karşılaşılabileceklerini ve çocuklarının sokağa çıkamayacak hale geleceğini öne sürmüşlerdir. Mahalle halkı durumun zabıta aracılığıyla da önlenemeyeceğini düşündüklerinden içki satışının kaldırımasını talep etmiştir (BOA., ŞD., Dosya no: 2922, Gömlek no: 51). Gazinonun kapatılması yerine içki satışının yasak edilmesi talebi olumlu görülse de içki satışının gazinoların ayakta kalması için önemli bir gelir kaynağı olduğu unutulmamalıdır. Bu sebeple içki satışının kaldırılmasının ilerleyen zamanlarda gazinonun da kapanması anlamına geleceğini söylemek gerekir. 
Kimi zaman mahalle halkını mahalle imamlarının yönlendirdiği ve gazinoların kapatılması için önayak oldukları görülür. Mihal'in yazdığı dilekçede Aksaray'da bulunan gazinosunun imam efendinin halkı galeyana getirerek kapatıldığı ifade edilmiştir. Mihal çalışmadığı için parasız kaldığını dile getirmiştir. Mihal'e göre gazinonun içinde diğer mahallerdeki gibi şerbet satılmaktadır. Gazinosunun açılması için birçok kez Zabtiye Müşiri'ne başvuru yapmışsa da itibar görmemiştir. Ayrıca gazinonun içindeki tüm eşya boşaltılarak dışarıya yığılmıştır (BOA., A.DVN., Dosya no: 137, Gömlek no: 31). Gazinodaki durumun Mihal'in anlattığı gibi olup olmadığı bilinmemektedir. Bununla birlikte, gizlice içki satışının yapıldığı ve halkın rahatsız olmasına neden olduğu ortamların da olabildiğini göz önünde tutmak gerekir. Cami ve tekkelere yakın yerlerde müskirat satışlarına izin verilmemekteydi.

1277 (1861) Nizamnamesinde, "Cami ve tekkelere iki yüz arşından yakın olan mahallerde, karakolhanelerin bitişiği ve karşılarında, sırf İslam mahallelerinde, umur-u zabıta ve usul-ü memleketçe mahzur görülen mevkilerde müskirat mahalli küşadına ruhsat verilmeyecektir." ifadesi yer almaktaydı (BOA, İ.MMS, Dosya no: 22, Gömlek no: 942, H. 9 N 1277/ M.21 Mart 1861). Dolayısıyla Osmanlı Devleti'nde camilere iki yüz arşından yakın mesafede meyhane veya içkili gazino açılması yasaktı. Hicri 1283 Nizamnamesi ile camilere yakınlık iki yüz arşından yüz arşına indirilmiştir. Söz gelimi, Kumkapı'da sahibi olduğu gazinoda, içki satmak isteyen Vartan Agobyan'ın ruhsat talebinin, gazino camiye yakın olduğundan kabul edilmediği görülmüştür (Özer, 2003, s. 254). Ancak bu kurallar çoğu kez gazino işletmecileri tarafından sorgulanmıştır. Lazaraki adlı bir şahsın sunduğu bir arzuhalde Atik Tavukpazarı'nda bulunan birkaç yıldır kiraladığı gazino ile civarında bulunan müskirat mağazalarına 25 gün önce Bâb-ı Vâlâyı Zabtiye tarafından müskirat satılmaması bağlamında emir verildiği ifade edilmiştir. Lazaraki verilen emre bağı olarak müskirat takımını kaldırıımışsa da civarında bulunan mağazaların kiracıları yabancı tebaadan olduklarından ileride verilecek karara kadar müskirat satılmasına izin almışlar ve Lazaraki de kahveden başka bir şey satamaz hale geldiğinden perişan duruma düştüğünden söz etmiştir. Civarındaki yabancı tebaadan kişilere izin verilip kendisi Osmanlı tebaasından olması nedeniyle bu izinden mahrum kaldığını dile getirerek merhamet beklemektedir. Lazaraki'nin gazinosunu keşfe gelen memurlar civarında bulunan camiye çok yakın olduğunu tespit ettiklerinden müskirat nizamnamesine bağlı olarak gazinoda müskirat satılmasını uygun bulmamıştır (BOA., MVL., Dosya no: 407, Gömlek no: 25).

Cami civarları yanı sıra türbe, okul gibi yapıların yakınlarında da gazino açılmasına izin verilmemekteydi. 3 Za 1268/19 Ağustos 1852 tarihinde İngiliz tebaasından Panayi Madkoylu (?) adlı şahsın Heybeliada'da bulunan ve bazı şartlarla gazino yapmak için kiraladığı kâgir hanenin açılması hakkında İngiltere Sefareti tarafından yapılan talep üzerine orada bulunan Bahriye Mektebi nedeniyle açılmasının uygun olmayacağına karar verilmiştir (BOA., A.MKT.MVL., Dosya no: 55, Gömlek no: 26). Gazino açılmasına engel olmak isteyen kişisel başvuruların da kabul gördüğü söylenebilir. Zabtiye Müşiri'ne yazılmış bir evrakta, Yeniköy'de gazino haline dönüştürülecek olan Mumcu Yorgi'nin un mağazasının sahilhanesine çok yakın olması nedeniyle Akil Bey tarafından istenmediği ifade edilmiştir. Akil Bey'in bu talebinin Yeniköy ahalisi tarafından da kabul gördüğü anlaşılmaktadır. İslam mahallesinde ve cami civarında olan böyle bir mahalde gazino açılması halinde meçhul bazı kişiler tarafından uygunsuzlukların ortaya çıkacağı düşünülerek gazinonun men edilmesi Yeniköy ahalisi tarafından istenmiştir. Sonuçta kahvehane yapmak ya da zararı olmayan bir esnafa kiraya verilmek üzere Yorgi'den senet alınmıştır (BOA., MVL., Dosya no: 832, Gömlek no: 106). 
Gayrimüslimlerin yaşadığı mahallelerde gazino açılmasına izin verilmektedir. Söz gelimi, Arnavutköy Vapur İskelesi'nde bulunan gazinoda müskirat satılmasına ruhsat verilmesi hakkındaki talep için Hıristiyan mahalle ve çarşısında bulunması gibi sebeplerle uygun olduğuna karar verilmiştir (BOA., MVL., Dosya no: 487, Gömlek no: 79). Ancak, Hıristiyan ve Müslüman ahalinin birlikte yaşadığı bazı mahallelerde gazinoların varlığı çoğunlukla Müslüman halk tarafından istenmemiştir. Hıristiyan mahallelerinde bulunan bazı gazinolar okullara gelir getirmek amacıyla işletilmektedir. Salmatomruk Rum milleti murahhası vekili Dimitri Apostolidi ve Salmatomruk Ermeni Milleti Murahhası Vekili İpiya Boncukciyan'ın 4 Mart 1290/16 Mart 1874 yılında yazdığı dilekçede Salmatomruk'taki gazinoların Rum ve Ermeni milletinden kız ve erkek sıbyan mekteplerinin akaratından olduğu ifade edilmiştir. Müskiratın satışı için daha önce verilen ruhsata bağlı olarak kilisenin mevcut nakdi gazinoların inşasına harcanmış ve 100.000 kuruş da mekteplerin borca girdiği belirtilmiştir. Müslüman ahalinin şikâyetinin kabul edilemeyeceğini kaydeden arzuhalde, bu mahallede yer alan meygedenin şikâyet konusu olmayıp da gazinoların şikâyet edilmesi sorgulanmıştır. Meygedenin kapladığı alan 60 arşınken 2-3 bin zira kadar hane arsası satın alarak genişlediği ve üç mahalleye çıkan üç kapı açtığı dile getirilmiştir. Asıl rezaletin bu tip meygedelerden ortaya çıktığı öne sürülerek Müslüman ahalinin bunun için hiçbir şey demeyip de şimdiye kadar "bir gün fenalığı olmayan ve sırf Hıristiyan mahallesinde nizam gereği duran üç gazino" aleyhine ayaklanmaları dilekçeyi kaleme alan Dimitri Apostolidi ve İpiya Boncukciyan tarafından anlaşılamamıştır. Dilekçede şu sorular sorulmaktadır: "bunların kiralarını biz veririz demeleri oradaki meygedecinin amacını desteklemek değil de ya nedir? İcar taahhüdü meygedeci tarafından verilip de görünürde ahalinin olması durumun ispatı değil midir? Bu gazinolar sırf Hıristiyan mahallesinde ve nizamı dairesinde olduğu ortadayken buna niçin mani oluyorlar?". Dilekçe sahiplerine göre nizama uygunluk yoksa oradan meygedenin de kalkması gerekmektedir. Dimitri Apostolidi ve İpiya Boncukciyan meygedede satılan müskirat için sessiz kalınıp da böyle uzak mahalde bulunan gazinolar hakkında mühür konmasının Kemankeş Mahallesi imamının teşvikiyle yapıldığı kanaatindedirler (BOA., ŞD., Dosya no: 2878, Gömlek no: 32).

Gazinoların varlık gösterdikleri mekânların yanı sıra faaliyet gösterdiği saat aralığı da çoğu kez tartışma konusu haline getirilmiştir. Sadece gazino işletmecileri değil halktan kişiler de gazinoların açık kalma süreci için mücadele vermiş görünür. Adana'da geceleri saat ikiden sonra gazinolarda ve çalgılı kahvehanelerde içki satışı ve tiyatro oynatılması yasaklandığı ve bu husus ahali tarafından kabul edildiği halde vilayet merkez kumandanı Binbaşı Şevki Bey ve akrabasından Mülazım Tevfik Efendi ile Avadis Gülbenkyan Efendi adında bir kişinin bu duruma karşı geldiği anlaşılmaktadır. Binbaşı Şevki Bey yasaklamaya ve polisin beyanatına rağmen içki içmeye devam etmiş, vazife anında zabıtayı tahkir etmiş ve ahaliyi de teşvik ederek zorla tiyatro oynatmıştır (BOA., DH. EUM.MTK., Dosya no: 7, Gömlek no: 22).

12 Safer 1300/23 Aralık 1882 tarihinde Galata gazinocuları Galata'da müskirat mağaza ve kahvehanelerinin gece saat beşe kadar açık bırakılmaktayken Galata zabıtası tarafından saat bir buçukta kapatılmaya başlandığını ileri sürerek kazançlarına sekte vurulduğunu dile getirmiştir. Dükkânlarının saat beşe kadar açık kalması için Galata gazinocuları tarafından sunulan arzuhal Dâhiliye Nezareti'ne gönderilmiştir. Alınan cevapta Galata'da resmi izin ile açılan tiyatrolardan başka kötü zan altında olmayan gazinoların gece yarısından bir saat sonraya kadar açık bulunduğu bildirilmiştir. Ancak çalgı ve kızlar bulunduran gazino ve birahaneler ile müskirat fabrikaları ve meyhanelerine gidenler kızlar aracılığıyla sarhoş edilmekte ve sonra borcunun birkaç katı ve üzerinde ne bulunursa zorla alınmaktadır. Kişilerin karşı koymaları halinde yaralama ve öldürme olaylarının olduğu ve bundan dolayı zan altında kalarak zabıta tarafından toplatılmalarına gerek görülen kişilerin de suç ve cinayet mekânı olan meyhaneler ile 
müskirat fabrikalarında saklandığı öne sürülmüştür. Bu tip gazino ve birahanelerin nizamlar gereği saat dörtte ve meyhaneler ile müskirat fabrikalarının bir buçukta kapattırılmakta olmasından halkı soymakla geçinenlerin şikâyet ettikleri ifade edilmiştir. Meyhaneler ve müskirat fabrikalarının saat bir buçukta kapattırıması memleketin asayişi ve düzeni için gerekli görülmüştür (BOA., ŞD., Dosya no: 2907, Gömlek no: 65).

1883 yılında Dersaadet ve bilâd-ı selâse'de bulunan müskirat mağazalarının kethüdası Lazaraki tarafından kaleme alınan bir arzuhal, müskirat satan lokanta, gazino ve meyhane gibi iş yerlerinin kapanma saatlerinin "gedikli" ${ }^{5}$ ve "gediksiz" olarak iki sınıfa ayrılmasının meslek erbabını huzursuz ettiğini göstermektedir. 19. yüzyılda asayişsizlik olmaması için bu tip yerlerin akşam saatlerinden sonra kapanması, mevsim ve yere göre kapanma saatinin Zaptiye Nezareti tarafından belirlenmesi istenmiştir. Nezaret tarafından gedikli meygedelerin ve tüm lokantaların alaturka iki buçuk, geri kalanlarının bir buçuğa kadar açık kalabilmelerine izin verilmesi "gediksiz müskirat mağazacıları ve fabrikacıların" itirazlarına sebep olmuştur. Gediksiz mağaza esnafı ve fabrikacıları devletin uygulamasının adil olmadığından yakınmışlardı. Lazaraki'nin anlatımından gediksiz esnafın sayıca fazla olduğu anlaşılmaktadır ${ }^{6}$. Gedikli sınıf tüm esnafın onda birini oluşturmaktayken onda dokuzu gediksiz faaliyet göstermekteydi. Böyle bir durumda azınlıkta kalan gedikli gruba saat iki buçuğa kadar izin verilip diğerlerine saat bir buçuğa kadar izin verilmesi hoş karşılanmamıştır. Lazaraki hiç kimseyi kayırmadan herkese eşit hak verilmesini istemiştir (BOA., DH.MKT., Dosya no: 1341, Gömlek no: 77).

Kendileri kadar vergi vermeyen gediklilere 'şerefli ve mu'teber' gözüyle bakıldığını ifade eden gediksiz mağaza esnafı, Şura-yı Devlet dâhil olmak üzere birçok makama durumu defalarca arz etmişlerdi. Bu şikâyetlere rağmen Şura-yı Devlet, lokantalılara verilen hakkı da kaldırıp yalnız gediklilerin iki buçuğa, geri kalan gediksiz namıla 'mu'teber gazino ve mu'teber tüccar unvanlı fabrikaların' bir buçuğa kadar açık kalmalarına müsaade etmişti. $\mathrm{Bu}$ mağazacılar kendilerinin de gediksiz olmalarına rağmen 'muteber' oldukları iddiasındaydılar. Şura-yı Devlet'in gediklilere alaturka iki buçuğa kadar izin verip kendilerine bir buçuğa kadar izin vermesini eleştirmekteydiler (Öztürk, 2017, s. 53).

1883 yılında Dimitri yazdığı arzuhalde Fener'de Kılburnu adlı mahalde Kadri Paşa'nın mülkü olan gazinoda kiracı olarak senelik 300 Lira kira ve gelirinden devlete ve diğerlerine 120 L., onu aşkın işçiye de aylık verdiğini dile getirmiştir. Dimitri'ye göre, gazino içinde bir lokanta bulunmakta ve gazinoya gidip gelenler de namus sahibi kişilerdir. Gazino içinde bir anlaşmazlık ve vukuat ortaya çıkmamıştır. Gazinonun içinde müşterilerin yemek yedikleri sırada akşam saat bir buçukta diğer ufak koltuklar (koltuk meyhanesi) gibi kapatılmasının kendisine maddi zararı olduğunu bildiren Dimitri, bu durumun müşterilere de zorluk çıkardığını dile getirerek devlet tarafından ortaya çıkarılan yasaklardan gazinonun ayrı tutulduğunu ve Şuray-ı Devlet'in kararı gereğince diğer meyhane ve koltuklardan da ayrı tutulma isteğini dile getirmiştir (BOA., ŞD., Dosya no: 2907, Gömlek no: 65). Dimitri'nin gazinosunun istasyon mahalline yakın olması

\footnotetext{
${ }^{5}$ Gedik hakkı daha çok vakıflarda, vakıf malı dükkanlarda faaliyet gösteren esnaf için kullanılan bir tanım olmakla birlikte, buradaki "gedikli"nin kullanımı imtiyaz ve ruhsat sahibi esnafı tanımlamak içindir.

6 "Balıkpazarı'nda üç aded gedikli meygede olup yirmi bir bab ve Limoncular ile seksen doksan bab gediksiz gazino ve fabrika ve lokanta ve mağaza bulunduğu ve Kumkapı'da kırk beş bab dükkan miyânesinde beş tane gedikli bulunup kusurları gazino ve mağaza olup Langa'da altmıs yedi bab gazino ve fabrika ve lokanta ve mağaza miyânelerinde yedi bab gedikli ve Samatya'da doksan bab miyanında on on iki aded gedikli bulunduğu ve bunlara mümâsil Balat Üsküdar ve Boğaziçlerinde ber-vech-i ma'rûz on dükkanda bir dükkan gedikli olup kusurları gediksiz gazino ve fabrika olup bunlar üç ve dörde münkasım olmak lazım geldiği halde birincisi fabrika olup bunun en adisi yüz liradan sekiz yüz liraya kadar vergi itasıyla mükellef olup ikincisi lokantalar olmakla ehl-i servet ve erbâb-ı tabî‘at akşamdan sonra gelir ta'âm eder kendi halinde orada biraz vaktini geçirir üçüncüsü gazinolar olup ashâb-ı namus ve erbâb-ı merakdan olanlar akşamdan sonra gelir teneffüz eder dördüncüsü koltuk tabir olunur mahaller ki işretin halis ve nefasetlisi nisbet üzerine bunlarda bulunur ve ehven suretle de satıır mağazacıları münsıf adamlar olduğundan müşterîlerini memnu ederler" (BOA., DH.MKT., Dosya no: 1341, Gömlek no: 77).
} 
dolayısıyla konum olarak diğer gazinolardan farklı bir özellik sergilediği düşünülmektedir. İstasyon civarında bulunan gazinolara devletin daha müsamahakâr davranması yolcuların gidiş geliş saatlerinin çok çeşitlilik göstermesiyle ilişkili olmalıdır.

3 Recep 1300/10 Mayıs 1883 tarihinde istasyonlarda bulunan lokantaların erken kapattırılması demiryolu ile geleceklere zorluk çıkaracağından Dâhiliye Nezareti'nden alınan emir gereğince Sirkeci İskelesi, Kumkapı ve Narlıkapı demiryolu istasyonlarında bulunan ve içlerinde yemek yenen müskirat mahallerinin açık tutulmasına izin verilmiş olduğu görülür. Yapılan tahkikata göre Kılburnu Gazinosu da o civar ahalisinin ve hariçten gelen birçok kişinin gezi mahalli içindedir ve gazinonun içinde lokanta bulunduğu için eskisi gibi geceleri saat iki buçuk-üçe kadar açık bırakılmasında sorun olmadığına karar verilmiştir. Ancak bu karar verilirken bazı başka gazino sahiplerinin de bu sürelerden istifade etme isteğinde bulunabileceği düşünülmüştür. Söz konusu gazino, ahalinin gezi yaptığı bir sahilde yer almakta ve içinde de bir lokanta bulunmaktadır. Bu sebeple eskisi gibi gece saat iki buçuk-üçe kadar açık bırakılmasında zabıtaya göre bir mahzur bulunmamaktadır. Söz konusu gazinonun saat iki buçuk-üçe kadar açık tutulmasına izin verilmesi ve bundan dolayı diğer gazinolardan da talep gelirse o zaman gereğine bakılmasına karar verilmiştir (BOA., ŞD., Dosya no: 2907, Gömlek no: 65).

Tanzimat sonrası değişimle ortaya çıkan eski- yeni, geleneksel- modern çatışması içki mekânları konusunda da kendini göstermekte; lokantacı, gazinocu, fabrikacı örnekleri modern mekânları temsil ederken, gedikli esnafı gelenekseli simgelemekteydi. Mekân sahipleri, kendilerini haklı gösterecek uygulama, belge ve gerekçeler öne sürerek bürokratik olarak devleti meşgul etmekte; kendi istekleri doğrultusunda kararlar çıkartmak için çabalamaktaydılar. Şura-yı Devlet, bu tartışmalara son vermek adına, 1886 yılında gedikli-gediksiz tüm meyhanelerin alaturka saat bir buçukta kapatılması yönünde karar çıkarmıştı. Ancak bu sefer gedikliler, kendilerinin devlete vergi ile mükellef olduklarını, gedikli olmayanlarla eşit şartlarda olmamaları gerektiğini, mağazalarının eskiden olduğu gibi iki buçukta kapanmaya devam edilmesini rica etmiştir (Öztürk, 2017, s. 54).

29.12.1330/9 Aralık 1912 tarihli bir evrakta ise gazinoların açılıp kapanma saatleri hakkında yeni bir düzenleme yapıldığı ve ilk iki maddede konunun ele alındığı görülmektedir. Buna göre birinci maddede "Her türlü gazino, kahve ve meyhane taraf-ı hükümetten tayin edilmiş bir saatte kapanacaktır. Iş̧bu saatten sonra ne gece kabul edilip de ve ne de kapalı kapı arkasında müşteri alıkonur bundan mâ'adâ hangi mahallerin hangi saatten evvel açılması memnû' olduğu dahi tayin edilmiş olacaktır. Müşteriler dahi muayyen saatten sonra açık bu gibi yerlerde kalamazlar" ifadesi eklenmiştir. İkinci maddede ise "fazla açık bulundurmak için müsaade-i mahsusa istihsali lazımdır. İşbu müsaadenamede saat tayin edilecektir" ifadesi ile gazinoların uzun süre açık kalabilmesi için saatlerinin özel izinle düzenlenebileceği belirtilmiştir (BOA., DH.EUM.EMN., Dosya no: 108, Gömlek no: 43).

\section{Gazinonun Mekânları}

Gazinolar bulundukları yere göre nitelendirilerek adlandırılmaktadır. Bulundukları yere göre kır gazinosu, sahil gazinosu, plaj gazinosu, istasyon gazinosu (Resim 3) olarak isimler almışlardır. Doğal güzelliklerin içinde yer alan gazinoların çoğunlukla oturma alanları ve masaların bulunduğu kısımlar yeşilliğin içine dağılmış, ağaç altı mekânlarda düzenlenmiştir. Bazıları üstü kapalı çardak biçimindeki bir strüktürün altında masa ve sandalyelerin konumlandığı örneklerdir. Kır, plaj ya da sahil gazinolarında müşterilere hizmet etmeyi sağlayacak kulübe biçiminde kapalı mekânlar yer almıştır. Müzikli olabilen bu tür gazinolarda yiyecek servisi de yapılabilmektedir. Kır gazinoları mütevazı 
görünümlü kısıtlı imkânlarla oluşturulmuş mekânlardır. Mutfak işlevi gören kapalı derme çatma bir baraka ile genelde çamların altına serpiştirilmiş tahtadan dört köşe küçük masalar, tahtadan iskemlelerden meydana gelen çitlerle çevrilmiş alanlardır. Çoğu kır gazinosunda laterna adı verilen ayaklı sandık biçimine, programlanmış melodiler çalabilen, bir kol vasıtasıyla kurulabilen mekanik bir çeşit çalgı ile bir dans pisti bulunurdu. Laterna İtalyan kökenli bir müzik aleti olup ilk defa 19. yüzyıl sonlarında Levantenler tarafından İtalya'dan getirilerek Bankalar Caddesi'ndeki mağazalarda satılmaya başlamıştır. 20. yüzyıl başlarından itibaren bu çalgının İstanbul'da ve Büyükada'da çok rağbet görmüş olduğu düşünülmektedir (Akpınar, 2017, s. 95). Büyükada'da eski kır kahvesi ya da gazinosu olarak kullanılan mekânlar bulunmaktadır (Resim 4). Bunlardan bazıları Dil Gazinosu (1-2), Aya Yorgi Gazinosu, Hristos Gazinosu, Belvü Gazinosu, Manol'un Gazinosu'dur? ${ }^{7}$. Bazı gazinolar otellerle birlikte anılmaktadır ve otellerin parçası olarak hizmet vermiştir. Söz gelimi, Belvü Otel ve Gazinosu, Kadıköy'ün gazino olmaya en uygun yerine kurulmuştur. Fenerbahçe Yarımadası'nın girişinde ve Kalamış Koyu üzerinde dar, ancak düzgün bir bahçesi ve ahşap bir otel binası bulunmaktaydı (Giz, 1998, s. 62).

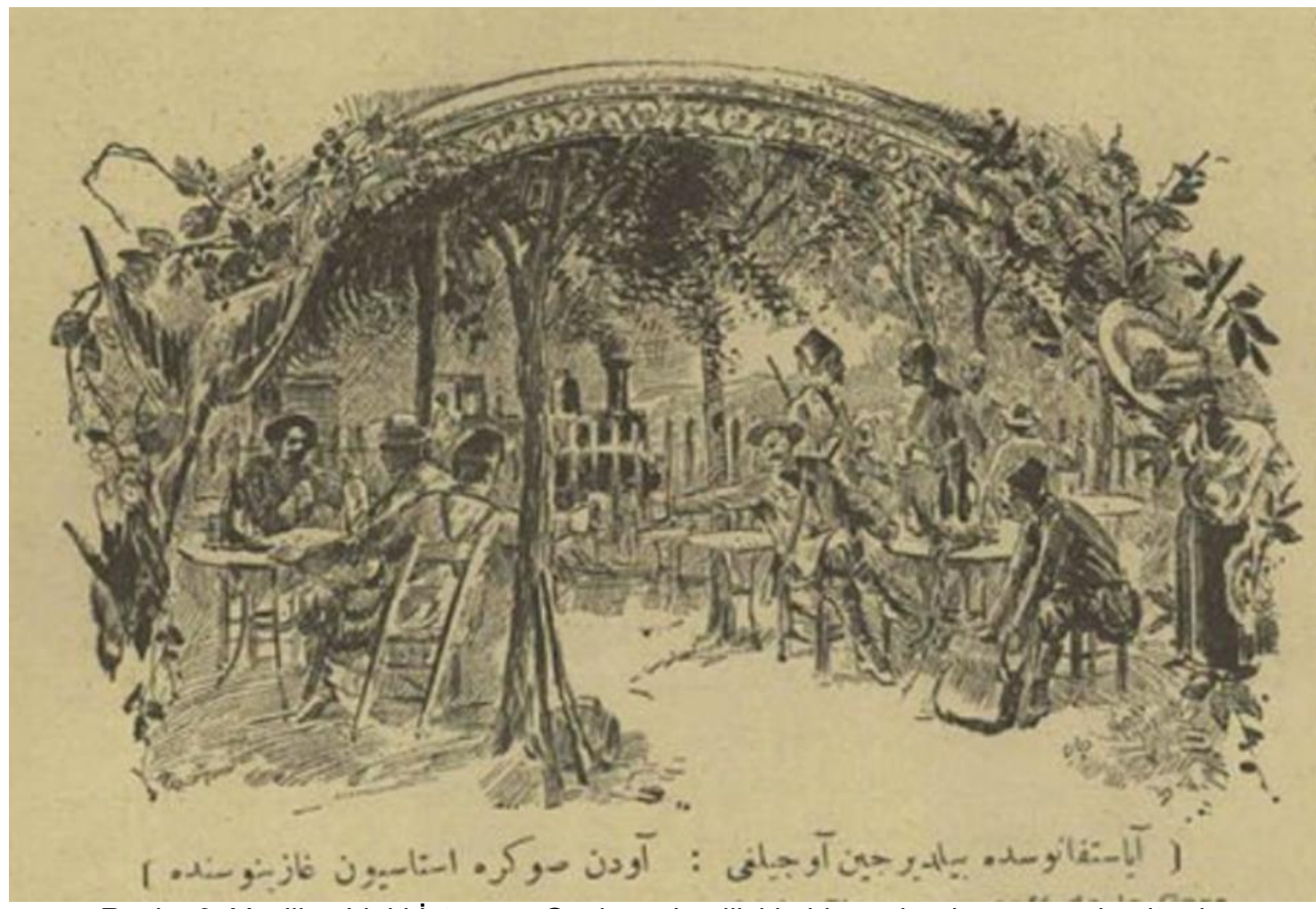

Resim 3. Yeşilköy'deki İstasyon Gazinosu'na ilişkin bir canlandırma resmin altında

"Ayastefanos'da bıldırcın avcılığı: Avdan sonra istasyon gazinosunda" yazmaktadır (Servet-i Fünun, S. 394, 1898, s. 53).

\footnotetext{
${ }^{7}$ Büyükada'daki diğer kır gazinoları şöyledir: Yörükali Gazinosu, Ramona Gazinosu, İstemati Gazinosu, Aşıklar Gazinosu, Viranbağ Gazinosu. Bkz. (Akpınar, 2014, s. 220-222).
} 


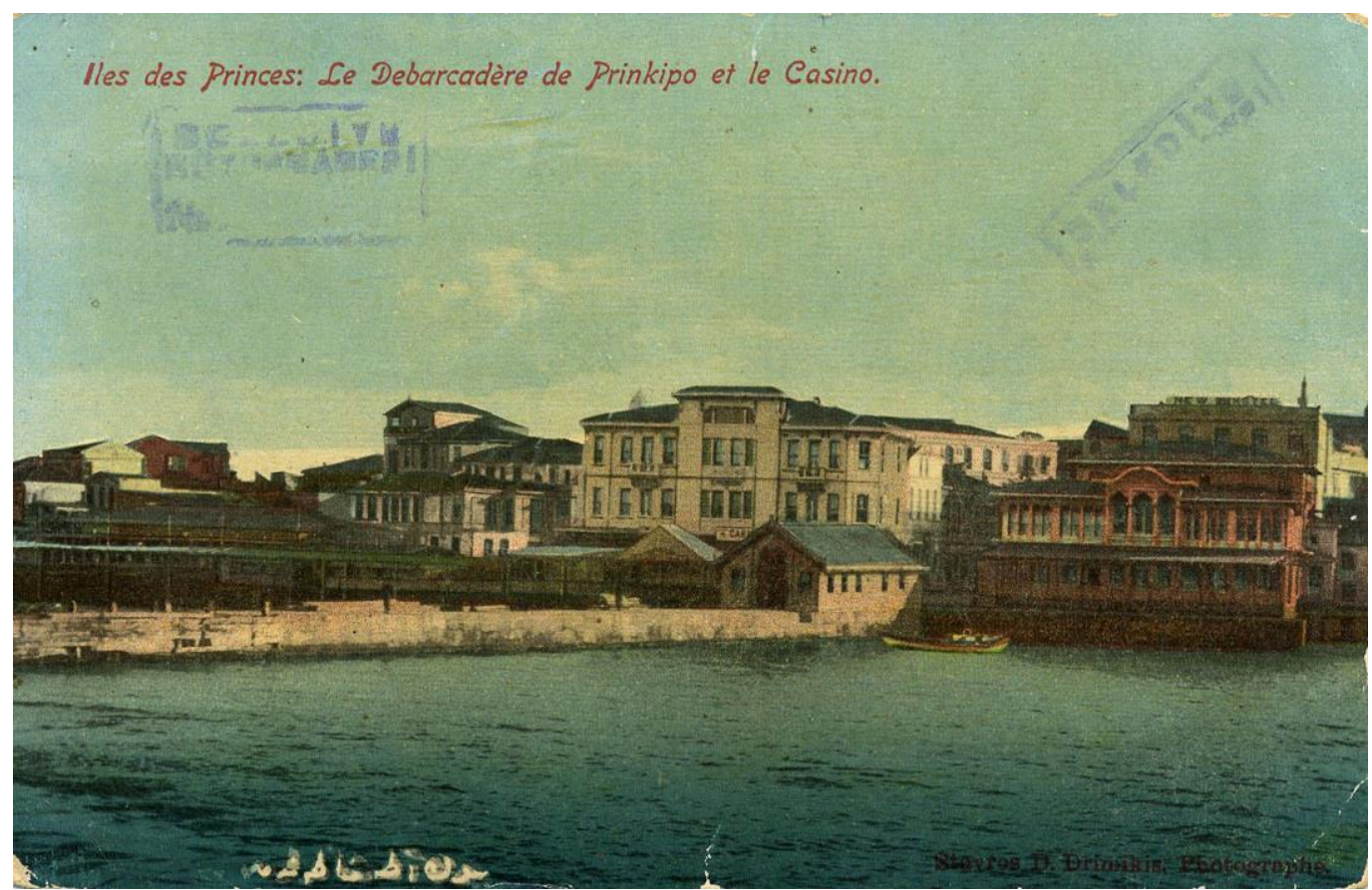

Resim 4. 1910 yılına ait bir kartpostalda Büyükada'da gazino (İ.B.B. Atatürk Kitaplığı, Krt_000819).

Arşiv belgelerinde çizimleri bulunan Göksu için tasarlanan bir gazino örneği yapının üst ve alt katında oluşturulan terasta oturma birimlerinin düzenleneceğini düşündürür. Böyle bir durumda yapının uzantısı olan alanların organize edilerek gazino için kullanıldığı söylenebilir (Resim 5) (BOA., PLK.p., Dosya no: 242). Eski Mühürdar Gazinosu böyle bir kullanıma örnek gösterilebilir. Bu gazino Moda'ya yakın bir yamaçta sona eren Mühürdar Caddesi'nin sonunda ve sol yanında orta büyüklükteki bir caddede kurulmuştur. Caddenin sağında ve denize bakan sırtta gazinonun kapalı büfesi ile birkaç masalık çıkması bulunmaktaydı (Giz, 1998, s. 62).

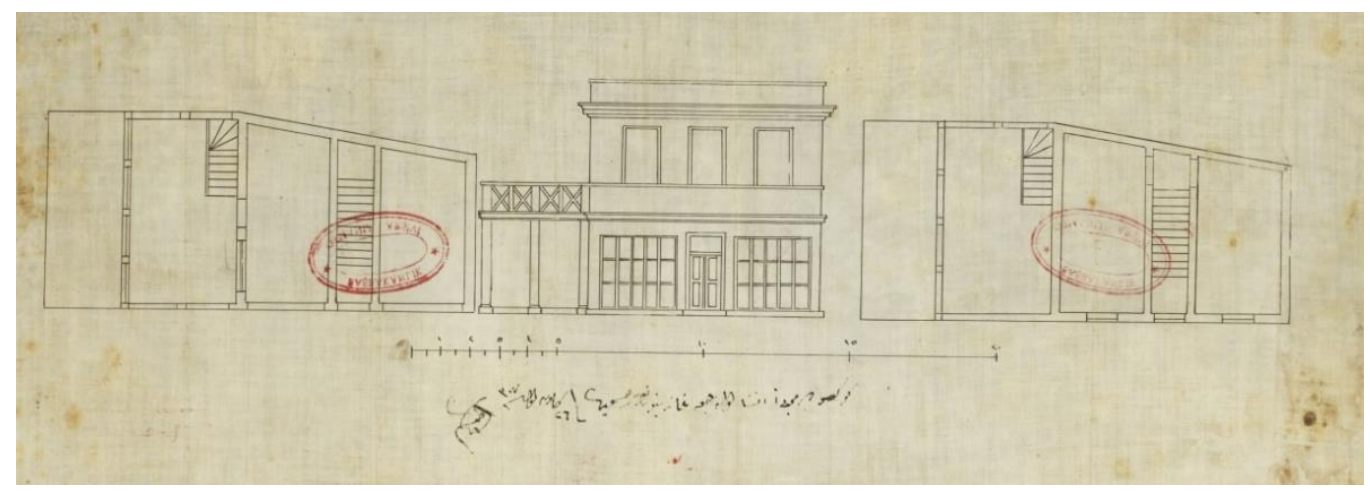

Resim 5. Göksu'da müceddeden inşâ olunacak gazinonun resmidir. Fi 26 Kanunuevvel sene [1]307/7 Ocak 1892 (BOA., PLK.p., Dosya no: 242).

Arşivde yer alan diğer gazino çizimi ise neresi için tasarlandığı belli olmayan bir örnektir. Plan ve cephe çiziminde bir tutarlılık görünmemekteyse de, mutfak ve aşçı dükkânı ile onlara hizmet veren mutfağın gazinoda yemek pişirildiğini gösterdiği söylenebilir. Bununla birlikte, pişmiş yemek istemeyen kişiler için atıştırmalıkların temin edildiği bir bakkal dükkânı da gazinoya hizmet etmektedir. Ayrıca kişilerin sigara intiyacını karşılayan bir tütün dükkânı bulunmaktadır (BOA., PLK.p., Dosya no: 3783). Müşterilerin ağırlandığı bölümün devamında gazinoya hizmet eden bölümler düşünülmüş ve gazino bir bütün halinde tasarlanmıştır (Resim 6). 


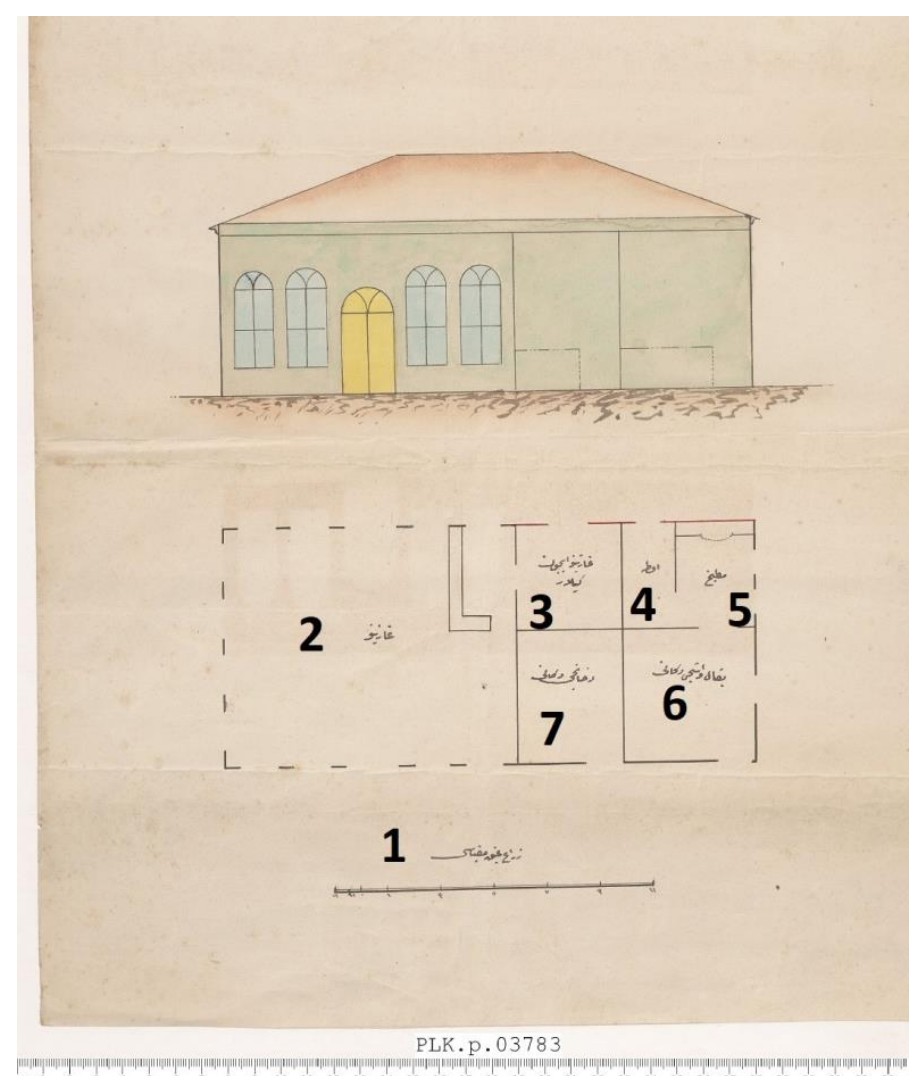

Resim 6. 1. Zirâ'-ı atîk mikyâsı, 2. Gazino, 3 Gazino için kiler, 4. Oda, 5. Mutfak, 6. Bakkal ve aşçı dükkânı, 7. Duhancı dükkânı, (BOA., PLK.p., Dosya no: 3783).

İstanbul'da sokak aralarında açılan bazı gazinolar da bulunmaktaydı. Hakkı Süha Gezgin, 20. yüzyılın başında İstanbul'un işgal günlerinde Sirkeci'de otel ve kahvehanelerin bol olduğundan söz ederken Ramazan ayında umulmadık yerlerde yeni yeni gazinolar ortaya çıktığını belirtir. Bu gazinoların "dört masa, sekiz sandalye, bir de gramafon"dan ibaret olduğunu kaydeder (Gezgin, 2019, s. 410). Müzikli gazinolar bulunmakla birlikte gazinolara dans pistleri çoğunlukla Cumhuriyet'in ilanından sonra ilave edilmiştir. Adnan Giz, Kadıköy Kuşdili'nde Hamdi'nin Gazinosu'nu anlatırken 1926 yılından sonra İstanbul'da başlayan dans merakı sebebiyle gazinoya dans pistinin yapıldığını ifade eder (Giz, 1998, s. 68).

Kimi zaman gazinoların mekânsal ihtiyaçları halktan gelen talepler doğrultusunda düzenlenmiştir. Söz gelimi Fener İskelesi Kılburnu denilen mahalde bulunan gazinonun üst katındaki alanın pandomim, komedya ve cambazlar için adaba ve terbiyeye uygun oyunlar sergilemek amacıyla bir oyun mekânına dönüştürülmesi talebi Hasköy ahalisinden gelmiştir. Oyun alanı yaptırılmasına başlanmasından sonra bu tip mahallerin binaları için Ebniye Meclisi'nden verilen ruhsattan başka Bâb-ı âlî'den de izin alınması gerektiğinden girişimde bulunulmuştur. Ancak bürokratik işlemlerin de bir taraftan doğru yürütülmesi önemlidir. İnşaatına başlanan oyun alanı için oldukça fazla para harcandığı halde Ticarethane tarafından yapılan kontroller sonucunda ruhsat alınmadığı ortaya çıkmış ve açılmasına izin verilmemiştir. Bu durum inşaatı yapan gazino sahibinin zarara uğramasına sebep olmuştur (BOA., MVL., Dosya no: 836, Gömlek no: 26).

Kır gazinolarında masaların doğal ortama yayılmaları sorun teşkil etmezken sokak aralarında kurulan bazı gazinoların sokağa nüfuz ederek geleni geçeni engelleyecek biçimde yayılmaları sorun yaratmıştır. Şehremaneti'ne yazılmış bir evrakta, Büyükdere'de bulunan İspanya Sefarethanesi önünde bulunan gazinonun sahibinin 
sokaktan bir miktar yer tutarak bahçeye dâhil etmek üzere duvar yaptığından söz edilmiştir. Duvarın ortadan kaldırılması için yapılan teşebbüsün boşa çıktığı belirtilerek, kamuya ait mahallere yapılan tecavüzün uygun bulunmadığı dile getirilmiştir (BOA., BEO., Dosya no: 33, Gömlek no: 2470). Başka örneklerde de cadde ve sokaklarda kahvehaneler ve gazinolar önüne yola taşarak konulan ve gelen geçene engel olan iskemle, camekân ve mostraların çıkarılmaması için yapılan uyarıların dinlenmediği anlaşılmaktadır (BOA.,ZB., Dosya no: 602, Gömlek no: 57). 1913 yılına ait belediye zabıtalarının görevlerini içeren talimatta, kahve, gazino, lokanta ve yemişçi gibi esnafın, bağlı bulundukları belediye dairesinden ruhsat almadan eşyalarını dışarıya koymaları kesin biçimde yasaklanmıştır (Ergin, 1995, s. 901).

\section{Müdavimleri Açısından Gazinodaki Eğlenceler ve Sınırları/Sorunları}

Gazinolar, sahipleri tarafından müdavimleri muteber (itibarı olan) kişiler olarak tarif edilen mekânlardır. Bu görüşe yönetimin de katıldığı anlaşılmaktadır. Buna göre 1892 yılına ait bir belgede konuya kamu düzeni açısından yaklaşan devlet, "esâfil-i nâsdan" (halkın en aşağı takımı) olmayan üst tabakaya mensup Müslümanların meyhaneler dışında birahanelere ve gazinolara gitmesinde bir sakınca görmemiştir. Belgede meyhanelere göre gazino ve birahane gibi mekânlar "mu'teber" olarak ifade edilmiştir". Ancak gazinoların muteber olması her zaman muteber kişilerin gazinoya gitmesinde sınır olmadığı anlamına gelmemelidir. Bazı memurların görevlerine ilişkin talimatlarda gazinolara gitmemeleri istenmiştir (Ergin, 1995, s. 1796). Devlet hem gazinoya giden kişilerin cinsiyetine ve mesleğine bağlı olarak gazinoya gitmeleri ya da gitmemeleri hakkında yasaklamalar hem de gazinoya gidenlerin karşılaşacağı eğlencenin niteliğine dair sınırlar getirmiştir. Söz gelimi, kadınlar, öğrenciler ve hocalara gazinoya gitmemeleri için zaman zaman uyarılar yapıımıştır.

Emniyet-i Umumiye Müdürlüğü'ne, 20 Haziran 1316/3 Temmuz 1900 tarihinde yazılan bir evrakta Ayastefanos'ta İslam kadınlarının gazinolarda oturmakta olduğunun haber alındığı kaydedilmiştir. Bunun İslam âdâbına karşıt olması sebebiyle ne kadar kötü etki bırakacağına dikkat çekilerek, oralarda oturmamalarının uygun bir dille kendilerine tembih edilmesi gerekli görülmüştür (BOA., DH.MUI., Dosya no: 109, Gömlek no: 29). Diğer taraftan talebe ve alimlerin kahvehane ve gazino gibi haysiyetlerine ve ilimlerine uygun olmayan mahallerde eğlence ile uğraştıkları öne sürülmüş ve boş yere vakit geçirdikleri bu mekânlara gitmemeleri hakkında kendilerine gerekli tembihlerin yapılması medrese müfettişleri tarafından istenmiştir (BOA., DH. EUM.KADL., Dosya no: 11, Gömek no: 38). Devletin bazı kesimleri eğlenceden uzak tutma girişimleri gazinonun tüm gündelik faaliyetlerin rutin işleyişini bozacağı ve ibadeti sekteye uğratacağı düşüncesiyle gerçekleştirilmiştir. Diğer taraftan müşterilerin muteber kişilerden oluştuğu sıkça dile getirilmişse de bu durum gazinolarda hiç olay çıkmıyor anlamına gelmemektedir. Söz gelimi, Nimet-i Hüdâ Vapuru'nda görevli olup Kasımpaşa'da ikamet eden Bahriye Mülazımı Mustafa Efendi'nin Tepebaşı'nda Fransız tebaasından Jorom'un kiracı olduğu "Café de France" adlı gazinoya gidip müşterilere ve Jorom'a sövüp saydığı, silah gösterdiği belirlenmiştir. Bahriye Mülazımı Mustafa Efendi'ye bunu yaptıran sebep nedir bilinmemekle birlikte, asker olması nedeniyle yaptığının kendisine yakıştırılamadığı ifade edilmiş ve memurlara teslim edilmiştir (BOA., ZB., Dosya no: 313, Gömlek no: 97).

Zabıta memurları geceleri tiyatro, sinema ve gazinoları teftiş etmekteydi (Ergin, 1995, s. 1818). Gazinolar polis tarafından da izlenen ve kontrol edilen mekânlardı. Kimlerin gazinoya geldiği ve kimlerle görüştükleri çoğu kez denetlenmiştir. Hükümet'in izlediği gazinolar arasında Tokatlıyan'ı saymak mümkündür. Yerli ve yabancı müşterileri olan

${ }^{8}$ BOA, Y.A.HUS, 256/89, (21 Receb 1309/20 Şubat 1892. Aktaran (Erdinçli, 2019, s. 124, 159). 
Tokatlıyan Gazinosu'nda Sultan İkinci Abdülhamid'in ser-esvâbisi İlyas Bey'in bazı arkadaşlarıyla birlikte geceleri gizli salonlarda "müzakerât ve tertibât-ı hafiyelikte" bulunduklarına dair Pangaltı Polis Merkezi tarafından yazılan belge bu hususa kanıt oluşturmaktadır (Erdem ve Hanilçe, 2019, s. 1380).

Gazinoya gelen giden kişiler dışında gazinodaki eğlencelerin içerikleri de denetlenmiştir. Dâhiliye Nezareti'ne yazılan bir evrakta akşam gazinolarda yasak şarkılar söylendiğinin şimdiye kadar duyulmadığı ancak ihtiyaten gazinolara tebligat gönderildiği polis idaresinden bildirilmiştir (BOA., DH.ŞFR., Dosya no: 148, Gömlek no: 6). Şarkıların sözleri, oyunların metinleri devlet aleyhine bir durum yaratmaması için önem taşımaktadır. Ayrıca programda belirtilen eğlencenin dışında, akıştaki bir değişiklik büyük intimalle gazinolardaki bazı izleyiciler tarafından yönetime haber verilmektedir. Söz gelimi, Yunan tebaasından Heybeliada'da Kaya adlı şahsın gazinosunda Pazar geceleri tiyatro oynanacağı ilan edilerek seyirci toplanmışken Yunan tebaasından bir kişinin ortaya çıkarak eskilerden bir şeyler anlatacağını beyan edip, ahaliyi tahrike cüret etmiş olduğu haber alınmıştır (BOA., HR.MKT., Dosya no: 162, Gömlek no: 32).

François Georgeon'a göre Ramazan boyunca Osmanlı iktidarı herhangi bir Karagöz gösterisine, bir tiyatro temsiline hatta film gösterimine sansür uygulayabilmektedir. Yetkililerin tek kaygısı bu gösterilerin kamu nizamını bozması, ahlaka ve dine halel getirmesidir. Tiyatro etkinlikleri sıkı biçimde gözaltında tutulmaktadır (Georgeon, 2018, s. 129). Ancak belgeler bunun sadece Ramazan ayı ve sergilenen oyunlarla ilgili olmadığını ve sanatçıların da aşırı kontroller nedeniyle zor zamanlar geçirdiğini göstermektedir. Herhangi bir devlet görevlisi gazinolarda faaliyet gösteren oyunculara üst bir emirle istediğini yaptırabilmektedir. Söz gelimi bir belgede Şehremini Hüseyin Bey'in Kumkapı Merkezi Bölükbaşısı Han Mahmud Ağa'yı konağına çağırarak gazinosunda oyun oynayan kız ve oğlanı konağına getirmesini istediği kaydedilmiştir. Gözdağı olarak görülen bu olay sebebiyle Mülazım-ı evvel Hacı Mustafa ve Kumkapı Merkezi Bölükbaşısı Han Mahmud Ağa'nın ifadesi alınmıştır (BOA., A.M., Dosya no: 19, Gömlek no: 19). Zabtiye Müşiri'ne yazılmış bir başka evrakta ise Yenikapı civarında bir gazinoda oyun oynamak üzere zabtiye marifetiyle resmen izin verilmiş olan bir Ermeni kumpanyasının tüm oyuncularının Şehremini tarafından hapse atıldığı haber verilmiş ve bu hareketin gerçek sebebinin ne olduğunun anlaşılması istenmiştir (BOA., A.MKT.NZD., Dosya no: 274, Gömlek no: 74).

Sıkı denetimin sebeplerinden diğeri gazinolarda kumar oynatılmasıdır. Örneğin Beykoz Parkı civarında bulunan bazı gazinolarda alenen kumar oynatıldığı tespit edilmiştir (BOA., DH.I.UM., Dosya no: 19, Gömlek no: 1). Diğer taraftan, Makriköy'de istasyon civarında bulunan bir gazinoda her gece sabahlara kadar kumar oynandığı ve gündüzleri bu gazinoya gelen Müslümanlar tarafından oruç bozulduğu haber alınmıştır. Yerel memurların bu duruma hoşgörü ile yaklaştığı ancak kanunen ve şer'an yasak olan kumarın oynanmaması için kutsal günlerde daha dikkatli olunması gerektiği bildirilmiştir. Alenen oruç bozmanın İslamiyet'e aykırı olması nedeniyle kumarın men edilmesi istenmiştir (BOA., ZB., Dosya no: 479, Gömlek no: 56).

Diğer taraftan 1918-1919 yıllarından sonra bir talih oyunu olan tombalanın ilk kez İstanbul'a sığınan Beyaz Ruslar tarafından Arkadi Gazinosu'nda başlatıldığı ifade edilmekteyse de (Zat, 1994, s. 379), söz konusu tarihlerden önce tombala oyununun oynatıldığı tespit edilmiştir. 15 Haziran 1305/27 Haziran 1899 yılına ait belge ile tombala oyununa önceleri izin verilip sonradan yasaklandığı ortaya çıkmaktadır (BOA., DH.MKT., Dosya no: 1622, Gömlek no: 107). Beyoğlu'nda Hanaki adlı mahalde eskiden beri oynatılan ve hükümet tarafından men edilen tombala adlı oyunun tavla ve bilardo türünden olduğu ve oynatılmasına izin verilmesi isteği Jak Hason imzasıyla Sadaret'e 
sunulmuştur. Zabtiye Nezareti ile yapılan yazışmalarda söz konusu oyunun tavla ve bilardo cinsinden olduğu öne sürülerek, üç yıl adı geçen gazinoda oynatıldığı ifade edilmiştir. Tombalanın kumar gibi kimsenin zarar etmesine, kavga ya da gürültüye sebep olmadığı öne sürülmüşse de şifahi bir irade ile men edildiği anlaşılmıştır (BOA., DH.MKT., Dosya no: 1599, Gömlek no: 88). Sadaret, oyunun oynatılmasında mahzur görmemiş ancak mutasarrıflık tekrar men edilmesini istemiştir (BOA., DH.MKT., Dosya no: 1622, Gömlek no: 107). Galatasaray civarında Hanaki adlı gazinoda tombala oynatıldığı gibi Galata'da ve Beyoğlu'nda da iki gazinoda daha tombala oyununun oynatılmasına izin verilmesi hakkında Sadaret'e arzuhal verilmiştir. Ancak yönetim tombalanın sermayesi az olanları zarara soktuğu ve kumarın en "muzır" çeşidi olduğu kanaatindedir. Hanaki Gazinosu'nda oynatılmasına izin verilmemesinin kamunun yararına olacağına karar verilmiştir. Ayrıca Hanaki Gazinosu'nda oynatılmasına izin verilmesinin bir emsal teşkil edeceği düşünülerek tümüyle yasaklanması uygun bulunmuştur (BOA., DH.MKT., Dosya no: 1777, Gömlek no: 30).

Kısa tiyatro oyunları ve operetler, türküler, konferanslar, hükümetten izin alınarak tiyatro içinde, gazino veya restoran bahçelerinde gerçekleşmiştir (BOA., DH.EUM.EMN., Dosya no: 108, Gömlek no: 43). Gazinolarda sirk gösterileri de yapılmaktaydı ancak bunlar için çeşitli tedbirler alınmıştır. Öncelikle izleyicilerin oyuncular veya hayvanlar tarafından rahatsız edilmemelerine ve dokunulmamalarına dikkat etmek gerekliydi. Her türlü tedbirin yangın tehlikesini de dikkate alarak sağlanması kural haline getirilmiştir. İp veya yüksek trapezler üzerinde yapılan tehlikeli oyunlar için emniyet ağlarının kurulması ve ip üzerinde oynayanların yanlarında çocuk çıkarmamaları zorunluydu (BOA., DH.EUM.EMN., Dosya no: 108, Gömlek no: 43).

Rumların Âpokriye (Apakurya) adını verdikleri karnaval döneminde gazinolarda maskeli balolar verilmiştir. Gazinolardan sokağa taşan eğlencede maskeli kişileri görmek mümkündür. Fener, Yenikapı, Yedikule, Tatavla gibi Rum mahallelerinde maskara kıyafetine özenenler varsa da asıl kutlamalar Beyoğlu'nda gerçekleşmiştir (Saraçoğlu, 2005, s. 211). Suriçinde yaşayan Türklere kendini göstermekten korkan bu grubun eğlenceleri taşkın gösterilere de dönüşebilmekteydi. Karnavala ait kutlamaların kapalı mekânlarda ve özellikle Beyoğlu gazinolarındaki balolarla gerçekleştiği görülmektedir. Her cemaat kendi balosunu yapmaktaydı. Afişlerle duyurulan Rum, Ermeni, Yahudi, İtalyan balosu birbirini izlerdi. Dans aksesuarları önceden yurt dışından ısmarlanırdı. Bu şenlikler, daha kalabalık olsun ve daha parlak geçsin diye bir elçinin himayesi altında yapılır ve birçok gereksinime de yanıt verirlerdi. Bu baloların yararlı ve hayırsever yönleri vardı. Toplanan hasılat eğlenceyi düzenleyen cemaatin hastane, okul gibi kurumlarına yardım olarak gönderilmekteydi (Bareilles, 2003, s. 73).

Karnaval döneminde ve diğer zamanlardaki balolarda ortaya çıkabilecek taşkınlıkları önleyebilmek için çeşitli kurallar konmuştur. Öncelikle balolar ya da maskeli balolar ve dans eğlenceleri yapabilmek için hükümetten izin alma zorunluluğu bulunmaktaydı. Eğlencenin gerçekleştirileceği gazino ya da işletmelerin müdürleri bu eğlencenin iyi biçimde idaresinden de sorumlu tutulmuş ancak bu konuda başarılı olamamaları halinde zabıtadan destek istemeleri önerilmiştir (BOA., DH.EUM.EMN., Dosya no: 108, Gömlek no: 43). Çalgı çalarak müşterilere sokağa kadar eşlik etmek yasaklanmıştır. Bu gibi durumlarda çalgıcı ya da işletme müdürü ceza almaktadır. Ayrıca maskeli baloların sokağa taşmaması, yapıldığı yerle sınırlı tutulması uygun görülmüş olmalıdır. Maskeli balolarda giyilen kıyafetlerin yönetimin koyduğu kurallara aykırı olma olasılığı bu düşünceyi desteklemektedir. Çünkü resmi ya da ruhani kıyafetler ya da maskelerle sokakta dolaşmak ve ahlaka aykırı kıyafetler giymek yasaklanmıştır (BOA., DH.EUM.EMN., Dosya no: 108, Gömlek no: 43). 
Beyoğlu ve Galata'da bulunan pek çok gazino büyük balolara sahne olmuştur. Bu tip balolar yapılabilmesi için gazinoların müdavimleri talepte bulunmuştur. 4 Ra 1268/28 Aralık 1851 tarihinde Kokini ve Sala adlı kimseler tarafından sunulan arzuhalde Beyoğlu'nda bulunan Büyük Gazino'nun sahipleri olduklarını söyleyerek bu gazinoda Beyoğlu ahalisine büyük ve süslü maskeli balolar verilmesi için gazino üyeleri tarafından talepte bulunulduğu bildirilmiştir. Gazinolarda yapılacak birkaç balonun Beyoğlu halkının muteber kesiminden olan ailelere ait olacağı dile getirilmiştir (BOA., MVL., Dosya no: 245, Gömlek no: 80).

1855 yılında açılan Palais Des Fleurs, 1862 yılında el değiştirmiş ve gazinoya dönüştürülerek büyük balolara ev sahipliği yapmıştır. Palais Des Fleurs'ün bahçesi yeniden düzenlenerek, iyi bir orkestranın çalacağı açık alana, kapalı kısmının da üye olunarak girilecek bir gazinoya dönüştürüldüğü ayrıca içerisinde okuma ve bilardo salonlarının oluşturulduğu görülür. Bu gazinonun etkinliği 1870 Pera yangınına kadar sürmüştür. 19 Ocak 1870 yılında yayınlanan bir gazete haberinde karnaval akşamlarının başladığı, bu nedenle Palais Des Fleurs'ün geniş ve zengin salonunun büyük bir zarafetle dekore edildiği duyurulmaktadır (Akın, 2002, s. 284). Pera Caddesi üzerinde yer alan Palais de Crystal ise M. Salla tarafından yaptırılan büyük bir çalgılı gazinodur. Bölgede önemli balo salonları arasında adı sıkça geçen Palais de Crystal, 25 Ocak 1862 yııında açılmıştır. Kalorifer tesisatı yapılarak salonların iyi ısınması sağlanmıştır. Ayrıca yemek servisi hizmetinin Hotel de France'ın sahibi M. Mayer tarafından düzenlendiği belirtilmektedir (Akın, 2002, s. 285-286).

Gazinolar batı ve doğu eğlence biçimlerini imparatorluğun başkentine taşımıştır. Balodan meddaha, karagöz oyunlarından tiyatroya kadar her müşterinin eğlence tercihine göre farklı programların uygulandığı tespit edilmektedir. Söz gelimi Basiretçi Ali Efendi Sirkeci İskelesi Caddesi'nde bulunan Bahçeli Gazino'ya gittiğinden söz ederek, burada Mısır ve Şam hanende ve sazendelerin bulunduğunu birkaç saat onları dinlediğini ifade eder. Konuya eleştirel bir biçimde yaklaşan Basiretçi, başka gazinolarda bu sazendelerin bulunmadığını dile getirerek davul, zurna, tef ve dümbelek gibi çalgılar çalındığını ve bu aletlerin insanın kulağını sağır ettiğini dile getirir. Buna rağmen halkın yine de bu gazinoları doldurduğuna dikkat çeker (Basiretçi Ali Efendi, 2017, s. 191). Halkın maddi durumlarına göre her türlü eğlenceye ilgi göstermiş olduğu düşünülebilir.

Gazinolar müzik programları yanında tiyatro ve pandomim gösterilerine de yer verirlerdi. Gazinolarda tango, fokstrot, çarliston danslarını Beyaz Ruslar tanıtmıştır. 1910'ların sonlarından 1920'lerin sonlarına kadar içki ve eğlenceyle “deniz hamamı"nı birleştiren, plajla bütünleşmiş gazinolar moda olmuştur (Emiroğlu, 2012, s. 591). Ahmet Rasim, Odeon adlı çalgılı gazinoda soğuk kış gününde alafranga, alaturka dansları ve şarkıların, manilerin söylendiğini anlatmıştır (Demir, 2018, s. 44). Sermet Muhtar Alus'a göre, Fener'de iskelenin bitişiğindeki Kılburnu Gazinosu 20. yüzyılın başlarında ince sazlı ve en rağbet edilen gazinolarındandır (Alus, 1997, s. 152). Ayrıca Moda Palas Otelleri ve önlerindeki gazinolardan kayık yarışları ile yağlı direklerden denize yuvarlananlar seyredilmektedir (Alus, 1997, s. 203).

Meddah oyunlarının sergilendiği yerler Babıali Caddesi Bahçeli Gazino; Eyüp Sultan İskele Gazinosu'dur. Karagöz oyunu Kasımpaşa'da Trabzonlu Kamil Efendi Gazinosu'nda, ortaoyunu ise Kumkapı Gazinosu'nda sergilenmektedir (Gürbüz, 2020, s. $9,18,21)$. Ortaoyunu aslında meydan oyunudur dolayısıyla büyük mekânlara intiyaç duyulmuştur (Ozansoy, 2019, s. 62). Bu sebeple büyük gazinolarda oynanmış olmalıdır. Kukla oyunları (Ozansoy, 2019, s. 71) ve tuluatın başlangıcı olan "Çıngırak" adlı oyun da bir gazinoda icra edilmiştir (Toparslan, 2018, s. 69). 


\section{Sonuçlar}

Adını yabancı bir sözcüğün (casino) anlamının bozulmasıyla alan "gazino"nun Osmanlı'da yer edinebilmesi, gazinonun kısmen geleneksel mekânlara tercüme edilmesiyle mümkün hale gelmiştir. Kahvehane gibi geleneksel mekânların gazinoya dönüşümünde 19. yüzyılın değişen zevk ve eğlence anlayışı etkili olmuştur. Bir taraftan kahvehane gibi geleneksel mekânlardaki çözülmeler ve içki-müzik, içki-yemek gibi yeni hizmetlerin ilavesi bir taraftan da gazinonun anlamına ve kullanımına uygun yeni mekân arayışları doğulu ve batılı eğlence türlerini içinde barındıran yeni bir eğlence mekânının ortaya çıkmasını sağlamıştır. Bu yeni eğlence mekânı belgelerde de ifade edildiği gibi müdavimleri "muteber" kişilerden oluştuğu öne sürülerek hizmete sokulmuştur. Ancak bu sözcüğün tam olarak ne tarif ettiği anlaşılamamakla birlikte gazinoya gelenlerin itibarlı olup olmadığının nasıl anlaşılacağı sorusu da akla gelmektedir. "Muteber" kişiler ifadesiyle muhtemelen zengin, giyim kuşamı yerinde ve adab-ı muaşeret kurallarından haberdar kimselerden söz ediliyor olmalıdır. En azından "muteber" tanımından bu kişilerin gazinoda nasıl davranacağını biliyor olması gerektiği anlaşılabilir. Bu tanımlardan bir gazino müşterisi profili yaratılmaya çalışılmakta ve asla sarhoş ve kavgacı müşterilerin gazinoya girmediğine dair bir kanı oluşturulmaktadır. Ancak buna rağmen gazinolarda silah çekme, küfür, kavga gibi pek çok huzur bozucu olaylarla da karşılaşılmaktadır. Kuşkusuz içkinin olduğu mekânlarda sakin bir ortamın sürekli olması beklenemez. Gazinoların açılmasına verilecek izinlerin hızlandırılması için müdavimlerinin "muteber kişiler"den oluştuğu söylenerek gazinoların hitap ettiği hayali bir sınıf kurgusu yapılmış olmalıdır. Diğer taraftan refahın yarattığı bir eğlence mekânı olduğuna dair kanının güçlendirilmesine de çalışılmıştır. Fiyata, kaliteye, talebe göre eğlence mekânlarında ihtisaslaşması söz konusudur.

Ince sazdan tuluata, pandomimden Karagöz'e kadar hem geleneksel hem de batılı eğlence anlayışına hitap eden gösteriler modernleşmeye çalışan Osmanlı toplumunun karışık eğlence anlayışını gazinolarda sergilemiştir. Ancak eğlencenin dozunu sürekli kontrol altında tutmak isteyen yönetim gerek zaman gerekse mekân açısından gazinoları devamlı denetlemiştir. İslam anlayışına uygun olmadığını düşündüğü noktalarda gazinoya giden bazı kesimlerin ve kadınların orada bulunmamaları için uyarıda bulunmuştur. Toplumun huzuruna ve güvenliğine tehdit olarak gördüğü içki satışını kontrol altında tutmuş, gazinolarda satış iznini kolaylıkla vermemiştir. Eğlence ve sarhoşlukla baş etmek gibi dünyevi işler için gazinoların cami, okul ve türbe yakınlarında olmaması ve gayrimüslim mahallelerinde yer alması uygun bulunmuştur. Eğlencenin süresi ve mekânı sınırlandığında kişilere zararının daha az olacağı düşünülmüştür. Sarhoş insanların kandırımalarının ve zarara uğramalarının önüne geçmek de bu sınırlamaların nedenlerindendir. Müslüman mahallelerinde gazino açılması mahalleli tarafından istenmemiş ve çoğu kez imamlar aracılığıyla ve çeşitli dilekçelerle bu şikâyetler merkeze iletilmiştir. Devletin genel kararı gazinoların gayrimüslim mahallelerinde açılması üzerinedir. Devlet gazinoları marjinal mekânlar olarak görmüş ve gayrimüslim mahallelerine hapsetmek istemiştir. Böylelikle İslam adabına aykırı bir yaşam biçiminin önüne geçileceği düşünülmüş olmalıdır. Gazinoda icra edilecek olan eğlence programı da kontrol altında tutulmakta ve gazino müdavimleri arasında olan kişiler tarafından yönetime bildirilmektedir. Gazinodaki oyuncuların da iş yapma koşullarının zorluğu dikkat çekmektedir.

Osmanlı yönetimi gazino açma taleplerine tedirgin yaklaşmış ancak emsalleri göz önünde tutarak karar vermiştir. Emsallerde huzur bozucu vukuatların olmaması gazinoların açılması için etkili bir çıkış noktası olmuştur. İçki satan esnafın içinde gediksizlerin sayıca fazla olması gedikliler lehine çıkan kararlara tepki verilmesine neden olmuştur. Dükkanların açık bırakılma saatlerine ilişkin farklar esnaf arasında 
huzursuzluğun başlıca sebepleri arasındadır. Gazinolar her şeye rağmen gerek devlete gerekse cemaatlere gelir getiren yerler olarak görülmüştür. Ermeni ve Rum cemaatlerinin okul yapılarının masraflarını karşılamak amacıyla işlettikleri gazinolar bulunmaktadır. Ayrıca pek çok gazinoda yapılan balolar ve davetler intiyacı olan cemaat üyelerine para toplamak için gerçekleşmektedir.

\section{Kaynaklar}

Akın, Nur (2002). 19. Yüzyılın İkinci Yarısında Galata ve Pera. İstanbul: Literatür Yayıncılık.

Akpınar, Nazan Sumer (2017). Anıların İzinde Büyükada'ya Yolculuk. İstanbul: Adalar Kültür Derneği.

Akpınar, Semiha (2014). Büyükada: Bir Ada Öyküsü. İstanbul: Adalı Yayınları.

Aliji, Perver (2019). Reşat Nuri Güntekin'in Romanlarında Eğlence Kültürü, Marmara Üniversitesi / Türkiyat Araştırmaları Enstitüsü, İstanbul.

Alus, Sermet Muhtar (1997). İstanbul Kazan, Ben Kepçe. İstanbul: İletişim Yayınları.

Bareilles, Bertrand (2003). İstanbul'un Frenk ve Levanten Mahalleleri: Pera-GalataBanliyöler, İstanbul: Güncel Yayıncılık.

Basiretçi Ali Efendi (2017). İstanbul Şehir Mektupları. İstanbul: Erdem Sedir Yayınları.

Deaver, G. Gilbert (1995). Eğlence. Clarence Richard Johnson, M.A. (Ed.), İstanbul 1920 içinde (s. 225-226). İstanbul: Tarih Vakfı Yurt Yayınları.

Demir, Mehtap (2018). Osmanlı Eğlence Hayatında Bir Alt Kültür Müzikli Kahvehâne: Amane Kahvehâneleri. Folklor/Edebiyat, 24/93, 35-53.

Duhanî, Said N. (1984). Eski İnsanlar Eski Evler: 19. Yüzyıl Sonunda Beyoğlu'nun Sosyal Topoğrafyası. İstanbul: TTOK.

Eğlence Hayatı. (1994). Dünden Bugüne İstanbul Ansiklopedisi içinde (Cilt. 3, s. 140144). İstanbul: Tarih Vakfı; Ankara : Kültür Bakanlığı.

Emiroğlu, Kudret (2012). Gündelik Hayatımızın Tarihi. İstanbul: Türkiye İş Bankası Kültür Yayınları.

Erdem, Ümit Baki, Hanilçe, Murat (2019). Mıgırdıç Tokatlıyan Otelleri, Gazinosu ve Lokantası-Cumhurbaşkanlığı Osmanlı Arşivi Belgelerine Göre-. MANAS Sosyal Araştırmalar Dergisi, 8/1, 1367-1390.

Erdinçli, İhsan (2019). Yenileşme Dönemi İstanbul'unda Meyhaneler ve Meyhanecilik (1826-1908). (Yayımlanmamış doktora tezi). KTÜ/Sosyal Bilimler Enstitüsü, Trabzon.

Ergin, Osman Nuri (1995). Mecelle-i Umûr-ı Belediyye, Cilt 2. İstanbul: İstanbul Büyükşehir Belediyesi Kültür İşleri Daire Başkanlığı.

Ergin, Osman Nuri (1995). Mecelle-i Umûr-ı Belediyye, Cilt 4. İstanbul: İstanbul Büyükşehir Belediyesi Kültür İşleri Daire Başkanlığı. 
Mekânın, Zamanın ve Eğlencenin Sınırlarında Osmanlı'da Gazinolar

Casinos in the Ottoman Empire at the Boundaries of Space, Time and Entertainment

Gazinolar. (1994). Dünden Bugüne İstanbul Ansiklopedisi içinde (Cilt. 3, s. 379-380).

Georgeon, François (2018). Osmanlıdan Cumhuriyete İstanbul'da Ramazan. İstanbul: Türkiye İş Bankası Yayınları.

Gezgin, Hakkı Süha (2019). İşgal Günlerinde İstanbul: 1920'lerden Cumhuriyet'e İstanbul'un Toplumsal Tarihi. İstanbul: Kapı Yayınları.

Giz, Adnan (1998). Bir Zamanlar Kadıköy. İstanbul: İletişim Yayınları.

Gürbüz, Zülal (2020). Geç Osmanlı Başkentinde Seyir Mekanlarındaki Değişim. (Yayımlanmamış yüksek lisans tezi). Gebze Teknik Üniversitesi / Fen Bilimleri Enstitüsü, Kocaeli.

Kabagöz, Murat Can (2016). Eğlenirken Modernleşmek Meyhaneden Baloza, İmparatorluk'tan Cumhuriyet'e İstanbul. Ankara: Heretik Yayınları.

Meriç, Nevin (2010). Osmanlıda Gündelik Hayatın Değişimi. İstanbul: Kaknüs Yayınları.

Müeyyed, Rıfat (1917). Medeni İhtiyaçlar: Kulüpler, Gazinolar. Yeni Mecmua: İlim, Sanat ve Ahlaka dair Haftalık Mecmua, 8, 147-148.

Ozansoy, Halit Fahri (2019). Eski İstanbul Ramazanları: Bütün Âdetleri Eğlenceleri Hatıraları Fıkraları. İstanbul: Dergâh Yayınları.

Özer, İlbeyi (2003). Mütareke ve İşgal Yıllarında Osmanlı Devletinde Görülen Sosyal Çöküntü ve Toplumsal Yaşam. OTAM, 14/14, 247-271.

Öztürk, Yeter (2017). XIX. Yüzyıl Arşiv Belgelerine Göre Osmanlı Devleti'nde İçki ve Yasakları. (Yayımlanmamış Y. L. Tezi). Ordu Üniversitesi/ Sosyal Bilimler Enstitüsü, Ordu.

Saraçoğlu, Ahmet Cemaleddin (2005). Eski İstanbul'dan Hatıralar. İstanbul: Kitabevi.

Sevengil, Refik Ahmet (2014). İstanbul Nasıl Eğleniyordu?. İstanbul: Alfa.

Toparslan, Mutlu (2018). XIX. Yüzyıl İstanbul Kültüründe Ramazan Eğlenceleri. (Yayımlanmamış yüksek lisans tezi). İstanbul Üniversitesi/Sosyal Bilimler Enstitüsü, İstanbul.

Türkçe Sözlük. (1992). TDK, İstanbul.

Yapar, Sena (2014). Modernleşme Projesinin Mekânı: Taksim Belediye Gazinosu (19391967). (Yayımlanmamış yüksek lisans tezi), İstanbul Bilgi Üniversitesi/Sosyal Bilimler Enstitüsü, İstanbul.

Yöre, Seyit (2012). Mekân ve Müzik: Osmanlı Döneminde İstanbul'un Çok Kültürlü Müzikli Eğlence Mekânları. Belleten, 76/277, 879-904.

Zat, Vefa (2005). Eski İstanbul Otelleri: İstanbul Hilton 50 Yaşında. İstanbul: Bilge Karınca.

Zat, Vefa (2019). Vefa Zat'ın Eski İstanbul'u ve Meyhaneleri. İstanbul: Oğlak Yayıncılık. 
Başkanlık Osmanlı Arşivi (BOA)

A.DVN., Sadaret Divan (Beylikçi) Kalemi Evrakı,

A.M., Sadaret Müteferrik Evrakı,

A.MKT.MVL., Sadaret Mektubi Kalemi Meclis-i Vâlâ Yazışmalarına Dair Belgeler,

A.MKT.NZD., Sadaret Mektubi Kalemi Nezaret ve Devair Yazışmalarına Ait Belgeler, BEO., Bâb-ı âlî Evrak Odası

DH.EUM.EMN., Dahiliye Emniyet Şubesi,

DH. EUM.KADL., Dahiliye Kısm-ı Adli Kalemi,

DH. EUM.MTK., Dahiliye Muharebat ve Tensikat Müdüriyeti,

DH.I.UM., Dahiliye İdare-i Umumiye,

DH.MKT., Dahiliye Mektubi Kalemi,

DH.MUI., Dahiliye Muharebat-ı Umumiye İdaresi,

DH.ŞFR., Dahiliye Şifre Kalemi,

HR.ID., Hariciye Nezareti İdare,

HR.MKT., Hariciye Nezareti Mektubi Kalemi Belgeleri,

HR.TO., Hariciye Nezareti Tercüme Odası,

I.MMS, İrade Meclis-i Mahsus,

MVL., Meclis-i Vâlâ

PLK.p., Plan-Proje-Kroki,

ŞD., Şura-yı Devlet

Y.A.HUS, Yıldız Tasnifi Sadaret Hususi Maruzat Evrakı,

ZB., Zabtiye Nezareti. 